\title{
MOVEMENT AND DELETION AFTER SYNTAX: LICENSING BY INFLECTION RECONSIDERED*
}

\author{
Andrés Saab \& Anikó Lipták
}

\begin{abstract}
In this paper we study the interaction between ellipsis and inflectional morphology and put forward a generalization about ellipsis blocking the application of some morphological operations. Working in the Distributed Morphology framework, we will demonstrate this generalization in the realm of NP ellipsis. We will show that NP ellipsis can lead to stranded affix filter violations, and that there are various strategies languages can resort to in order to resolve problems of convergence that stranded affixes cause at the PF interface. The resolution of the stranded affix filter configuration is responsible for the wellknown observation that heads preceding NP ellipsis sites need to show overt inflection in languages that inflect these heads (Lobeck 1995).
\end{abstract}

\section{Introduction}

In this paper, we take a close look at the interaction between ellipsis and morphology via the critical reconsideration of the alledged role inflection plays in the licensing of noun-phrase ellipsis (NPE), which we specifically define as ellipsis of a $n \mathrm{P} .{ }^{1}$ There is a long standing debate in the literature on NPE about the role inflection plays in ellipsis. In Lobeck's (1995) well established GB account, elided material is conceived of as an empty catergory, similar to and in some cases identical to, pro. As such, just like ordinary cases of pro in Rizzi (1986), pro forms instantiating ellipsis sites also need to be licensed via inflectional material. According to theories

\footnotetext{
*We are grateful for input on the material presented on these pages to two anonymous reviewers as well as Jeroen van Craenenbroeck, Roberta D'Alessandro, David Embick, Éva Dékány, Marcel den Dikken, Jairo Nunes, Mercedes Pujalte, Johan Rooryck, Eric Schoorlemmer, Tanja Temmerman, Pablo Zdrojewski, and the audiences of a syntax seminar at the Radboud University Nijmegen (2010), the Romance Lab at Leiden University (2011) and the workshop of Going Romance 2010. Thanks also to Lee Armishaw for proofreading the paper. The work of the second author was supported by $N W O$ (Netherlands Organization for Scientific Research).
}

\footnotetext{
${ }^{1}$ That is, with the term nominal ellipsis or noun phrase ellipsis we refer to ellipsis of the $n \mathrm{P}$ with the exclusion of the number projection and other categories of the extended nominal projection. As will become clearer below, this type of nominal ellipsis parallels the behavior of $v \mathrm{P}$ ellipsis in English in some relevant respects (see Saab 2004, 2008 for a detailed discussion on the size and syntactic distribution of $n \mathrm{P}$ ellipsis, and Merchant (2014) for a similar proposal).

Abbreviations used in this paper are: $\mathrm{ACC}=$ accusative case, $\mathrm{ADJ}=$ adjectivizer morpheme, AUX $=$ auxiliary, DAT $=$ dative case, $\mathrm{CL}=$ clitic, $\mathrm{F}=$ feminine, $\mathrm{LOC}=$ locative, $\mathrm{NOM}=$ nominative, $\mathrm{MSC}=$ masculine, $\mathrm{POSS}=$ possessive, $\mathrm{SE}=$ reflextive, $\mathrm{SG} / \mathrm{PL}=$ singular $/$ plural $\mathrm{PV}=$ preverb, $\mathrm{PRT}=$ particle, $\mathrm{VALID}=$ evidential marker
} 
that assume this kind of licensing, a head with certain inflectional properties (comprising a specific set of features) is able to license elliptical sites under the central notion of head government (Lobeck 1995).

With the introduction of the Minimalist Program, approaches based on government are no longer tenable, due to the fact that the notion of government no longer exists. As a result, there is no principled account of the licensing of NPE in the minimalist framework. Present-day approaches tend to shift their attention from this topic to other aspects of NPE (such as the identity relation or the status of the missing noun). When the issue of formal licensing arises, they argue that inflection does not play any role, contra Lobeck's findings, cf. López (2000), Bouchard (2002), Panagiotidis (2003), Ntelitheos \& Christodoulou (2005) or Eguren (2010).

This paper is dedicated to filling in this theoretical gap with regards to the role of inflection in NPE. Its core purpose is to throw a different light on the ellipsis-inflection connection. We will take Lobeck's generalization for NPE to be essentially correct, but will show that the role of inflection is epiphenomenal. In other words, there is no need for any licensing theory for NPE based on such morphological considerations. The licensing effects follow from the interaction between ellipsis (a syntactic operation with visible PF effects) and morphology, conceived here as a post-syntactic component of the grammar (Halle \& Marantz 1993, Embick \& Noyer 2001, and subsequent works in the Distributed Morphology framework).

Our main claim is that ellipsis blocks certain morphological operations. When this happens, ellipsis can create non-convergent outputs at PF. Assuming together with Chomsky (1995) that grammatical operations are only motivated by convergence at the interfaces, we predict that ellipsis triggers the application of morphological operations that take place in order to avoid problems of convergence at PF. We show in this paper that interactions of this sort do exist and are easily noticeable in syntactic domains in which morphological operations proceed. However, a note of caution is needed before we advance: the fact that grammatical operations are triggered by convergence reasons does not mean that they can 'see', or that they 'know', in a look-ahead fashion, the possible outputs of a given derivation. Indeed, we think of morphological operations as being 'blind' with respect to such outputs. It is for this reason that the term 'rescue', in this paper, should only be taken in a metaphorical way. An alternative way of thinking about the types of grammatical interactions we are exploring here is in terms of feeding relations. Thus, we will say that ellipsis feeds the application of certain morphological rules by creating the environment that triggers such rules. ${ }^{2}$

\footnotetext{
${ }^{2}$ We are grateful to an anonymous reviewer for helping us to clarify this point. See also section 3 and footnote 12 for more discussion.
} 
The prime empirical area of our investigation is NP ellipsis in two typologically unrelated languages, Hungarian, an agglutinative language, and Spanish, an inflectional language. Briefly illustrating the empirical domain which we are concerned with here, both languages require the presence of inflection on the remnants of NPE, if the elided noun is itself inflected and bears plural morphology. In Hungarian, plural marking in non-elliptical contexts shows up only on the noun, yet it must obligatorily occur on the last remnant of the elliptical site when nominal ellipsis applies:

(1) Mi a János mellett-i szék-ek-en ültünk. Ők a

we the János next-ADJ chair-PL-ON sat they a Péter mellet-i-[_] ]-ek-en.

Péter next-ADJ-PL-ON

'We sat on the chairs next to János. They on the chairs next to Péter.'

In Spanish, determiners must obligatory realize at least number affixes when the noun is elided:

(2) ¿Qué/cuáles libros de Borges y $\left\{{ }^{*} q u e ́ / \checkmark\right.$ cuáles $\}$ [_] de what/which.PL books of Borges and what/ which.PL of Bioy te gustan?

Bioy you like

'Which books of Borges and which of Bioy do you like?'

In theories like Lobeck's, both (1) and (2) are cases of NPE licensed by inflection. In the theory we will propose, however, the reason why number inflections survive in NP ellipsis is the direct consequence of the fact that this kind of ellipsis creates a stranded affix filter configuration (in Lasnik's 1981 sense) that calls for a morphological solution. As we extensively argue in this paper, the solution adopted depends to some extent on particular properties of languages. Thus, agglutinative languages tend to resort to Local Dislocation, a displacement operation at PF that applies under strict adjacency, whereas concord languages like Spanish delete the stranded number affix under identity with the agreeing number morpheme.

The paper is structured in the following way. In section 2, we briefly introduce the topic of NP ellipsis and the architectural assumptions we adopt and defend through this paper. In section 3, we introduce and illustrate what we will refer to as the ellipsis-morphology generalization, i.e., the fact that phrasal ellipsis disrupts the application of morphological operations at PF. We conjecture then that languages use different morphological strategies such as deletion, insertion and movement to circumvent convergence problems at PF. In section 4, we look at the effect of ellipsis in nominals in Hungarian and show that this language uses Local Dislocation to solve the stranded affix violations in NPE. In 
section 5 we consider Spanish, and spell out a proposal in terms of number deletion doing the rescueing. Section 6 concludes.

\section{General assumptions}

\subsection{NP ellipsis and the role of inflectional licensing}

NP ellipsis is ellipsis of part of a noun phrase, illustrated in example (3):

(3) John bought three apples. I have eaten two [apples].

The literature on NPE is sizable, starting from Ross (1967), Jackendoff (1977), and considers the lack of the noun in NPE to be an effect of an ellipsis operation (like PF-deletion) or the presence of an empty pronominal (see Corver \& van Koppen 2011 recently). We adopt the former view and take NPE to be an instance of a PF operation (or rather the lack of a PF operation, as we will specify below).

NPE is an ellipsis process that can only apply in case the meaning of the missing noun is recoverable from the linguistic or non-linguistic context. In a great deal of the literature on NPE, this phenomenon is said to be in need of formal licensing as well: the missing noun needs to be formally licensed by some type of overt agreement, inflection or a specific feature present on the stranded material, for example on the adjectival or numeral remnant. Consider the case of the German example in (4) with the singular neuter noun Kleid 'dress'. While the German adjective lila inflects optionally for number and gender in non-elliptical noun phrases like (4a), it is obligatorily inflected for these features when the noun is elided (Muysken \& van Riemsdijk 1986):
a. ein lila/linanes
Kleid
a lila/lila.SG.NEUT.NOM dress
'a lila dress'
b. *ein lila [_]
a lila
'a lila one'
c. ein lilanes [_]
a lila.sG.NEUT.NOM
'a lila one'

The generalization that connects the presence of agreement/inflection (realizing specific features) on the remnant and the possibility of NPE has given rise to the theoretical explantion in the GB framework that ellipsis is licensed under government — in such accounts, NPE sites are considered to contain a pro (in some versions, PRO) which needs to be licensed, just like ordinary cases of pro-drop (Rizzi 1986). In Lobeck (1995), for example, NPE requires head-government by an element with a strong feature, which can be $[+$ pl], [+poss] or [+partitive]. The types of 
features that license agreeement are called strong in her theory. Lobeck's crucial definition is given in (5): ${ }^{3}$

(5) Licensing and Identification of pro

An empty, non-arbitrary pronominal must be properly headgoverned, and governed by an $\mathrm{X}^{0}$ specified for strong agreement. (Lobeck 1995:20)

At the same time, it is also clear that there are languages and configurations where there is no overt realization of agreement or inflection - just like in (3), where the remnant two does not carry inflection of any sort, or in the Chinese example (6) where there is no agreement morpheme present (while de is obligatory) (Cheng \& Sybesma 2009):

(6) wǒ xǐhuān hóng-sè de xié, tā xǔhuān huáng-sè de [_]. 1s like red-color DE shoe 3s like yellow-color DE 'I like red shoes, he likes yellow ones.'

Lobeck (1995) was aware of this and proposed that the "amount" of overt inflection necessary to license the elided nominal (constituent) is proportional to the amount of overt inflection in any given language.

(7) The ellipsis idenficational parameter (Lobeck 1995 p.102)

The number of strong agreement features in DET or NUM that is required to identify an empty, pronominal NP is proportional to the number of possible strong features in the agreement system of noun phrases in the language.

In the minimalist framework the licensing of ellipsis is no longer defined in terms of government, but in terms of an ellipsis-specific licensing feature [E], an implementation that originates from Merchant (2001), and which we adopt for the purposes of this paper. [E] is merged with the head whose complement is to be elided, and it represents all the relevant properties that distinguish elliptical structures from their non-elliptical counterparts. Crucially, in the case of NP ellipsis, we take the [E] feature to possess an uninterpretable $[u \mathrm{Num}]$ feature that requires over checking against a number head. This $[\mathrm{E}]$ feature triggers ellipsis of the complement of Num, namely the $n \mathrm{P}$, following Saab $(2004,2008,2010)$ and Merchant (2014). ${ }^{4}$

\footnotetext{
${ }^{3}$ The licensing condition is defined differently in other works on the topic. Kester (1996a) states that NPE needs to be governed by a functional head hosting inflected adjectival phrases. Bernstein (1993) requires the precense of word-markers for the same reason. See also Alexiadou \& Gengel (2012) on the reincarnation of Bernstein's idea.

${ }^{4}$ With the use of the [E] feature, we do not claim to put in place an explanatory theory of formal licensing, rather we view it as the technical implementation of the observed patterns, namely, that ellipsis takes certain designated phrases as its target. The [E] feature ensures this in a mechanical fashion, but the relevant grammatical correlations that determine the size of a given elliptical phrase are obscure under the current understanting of the issue.
} 
Using the terminology of this [E]-feature based account, (5) would then equal the requirement for the [E] feature that triggers $n \mathrm{P}$ ellipsis to have some morphological correlate on the basis of the inflectional system of a given language. In this paper we will argue against this view, and show that the licensing requirements of NP ellipsis do not make reference to overt morphological material at all. Instead we argue that these requirements amount to the following configuration - the configuration we term $n \mathrm{P}$ ellipsis (or NP ellipsis) in this paper.

(8)

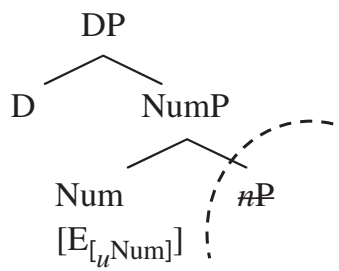

the syntax of $[E]$ in nominal ellipsis

Following this, we do not claim that no other category in the nominal domain might undergo ellipsis in languages. In some languages, other categories of the noun phrase might also elide (similarly to the sentential domain, cf. the discussion on NumP ellipsis in Spanish in section 5.1.) with properties distinct from $n \mathrm{P}$ ellipsis.

Our account in terms of (8) is crucially different from those proposals that treat the lack of inflectional licensers in languages like Chinese, (cf. 6 above) and similar data in other languages, as evidence for the claim that NPE does not need any formal licensing after all (cf. López 2000, Bouchard 2002, Panagiotidis 2003, and Ntelitheos \& Christodoulou 2005). It is also dissimilar to the claim that the licensor of NPE is not a feature related to inflection, but rather to a semantic specification, like contrastive focus (Eguren 2010) or partitivity (Sleeman 1996). Whatever the effect of focus or partitivity is in $\mathrm{NPE}^{5}$, it seems to us that a principled

\footnotetext{
${ }^{5}$ Although we do not address the relevance of focus or partitivity in NPE in this paper, it seems to us that contrastive focus is not required on the remnants in NPE. Cf. the example in (i) in Spanish or (ii) in Hungarian:
}

(i) Juan ha leído los cuentos de Cortázar y yo también he leído los [_] de John has read the stories by Cortázar and I also have read the-PL by Cortázar. Cortázar

'Juan has read the stories of Cortázar and I have also read the stories of Cortázar.'

(ii) János szürke autót szeretne. Egy szürké-[_]-t ugyanis nem kell sokat János grey car.ACC like.COND.3SG a grey-ACC PRT not need much.ACC mosni. wash.INF

'János would like to have a grey car. A grey one does not need much washing.'

(i) is an example from Eguren (2010), which the author takes to be contrastive, even though it is not the case that Cortázar has to contrast with other writers for (i) to be felicitous (see section 5 for more discussion of these types of examples in Spanish). Neither is it the case that (ii) must necessarily have a contrastive interpretation with respect to other colours in Hungarian. 
account is necessary for data like (2), repeated below as (9), for which focus and/or partitivity cannot be made responsible. What these data show is that in contexts where inflection is (at least) optional, inflectional morphology needs to be overt in case NPE applies.

(9) ¿Qué/cuáles libros de Borges y $\left\{{ }^{*}\right.$ qué $/ \checkmark$ cuáles $\}$ [_] de what/which.PL books of Borges and what/ which.PL of Bioy te gustan?

Bioy you like

'Which books of Borges and which of Bioy do you like?'

In this paper, we offer an account that captures these facts and is compatible with the position that NPE does not have any morphological requirement beyond the abstract presence of an [E] feature as in (8). We will endorse the generalization that inflectional material, when present in a noun phrase, has to survive in NPE, but we will link the presence of this material to the morphosyntactic effects of ellipsis. In sum, we argue that ellipsis eliminates the host of inflectional morphemes creating a configuration in which these are 'stranded'. These stranded affixes are then 'rescued' via various means such that they get spelled out on remnant material in the noun phrase. This is what makes their appearance obligatory, and not the fact that they need to license the missing NP.

\subsection{The framework: Movement and deletion after syntax}

Before entering the discussion of the interaction between ellipsis and inflection, we introduce our architectural assumptions about the grammar. We follow the Distributed Morphology view of grammar as proposed in Halle \& Marantz (1993), with the refinements introduced by Embick \& Noyer (2001), and Embick (2007) in connection with the operation of Morphological Merger. ${ }^{6}$

As is well-known, a main property of DM is separationism; i.e., syntax is abstract, in the sense that phonological information is not present in the syntax; such information is supplied late in the morphological component through a set of Vocabulary Insertion Rules that provide phonological content to the abstract morphemes that are the output of syntax. Crucial to this view is that Morphology can also alter the syntactic nodes by the application of a set of morphological operations mainly motivated by wellformedness considerations at PF. Among the operations refered to in the literature, Morphological Merger, the operation that accounts for several varietes of affixation processes across

\footnotetext{
${ }^{6}$ Our choice of this anti-lexcialist model of morphology is not arbitrary; in fact it is necessitated, as will be shown in section 4, by the facts of NP ellipsis in agglutinative languages, whose very existence provides unambiguous evidence for morphological processes that take place outside the lexicon.
} 
languages, is especially relevant for our argument. According to the theory developed in Embick and Noyer (2001), Morphological Merger comes in two guises: Lowering and Local Dislocation. The motivation for such a division is given by the locality conditions that allow affixation at PF: whereas Lowering proceeds under immediate locality, Local Dislocation happens under strict adjacency. Immediate locality is the relation between a head and the head of its complement. This is the structural condition that applies for T to $v$ lowering in English, where the relation between the affix and the verbal base can be interrupted by adverbs (Embick \& Noyer 2001:585; notice that the trace here and in 11b has no theoretical status and only indicates the origin of movement):

(10) John [тр $t$ [vр completely destroy-ed the opposition ]]

Other instances of affixation at PF require adjacency between the targets of the movement, such as is the case with superlative/comparative formation in English, where adverbs do interrupt the relation between the targets of movement (Embick \& Noyer 2001:565):

(11) a. Mary is the mo-st amazingly smart person ...

b. *Mary is the $t$ amazingly smart-est person ...

$\longrightarrow$

The difference between these two kinds of affixation processes can be accounted for if post-syntactic operations take place before or after the introduction of linearization statements. Once a linearization statement is introduced in the structure, adjacency becomes a relevant condition for displacement. Put differently, the locality conditions that define the limits between Lowering and Local Dislocation are not stipulated, but follow from the derivational nature of Morphology. The ordering relation between Linearization and the two instances of Morphological Merger we have briefly discussed so far is illustrated in (12) (where > stands for precedence): ${ }^{7}$

\footnotetext{
${ }^{7}$ In Embick \& Noyer (2001), Local Dislocation and Linearization occur concomitantly with Vocabulary Insertion. Evidence for this comes from the phonological sensitivity of Local Dislocation. However, see Embick (2007) for a reconsideration.
} 
(12)

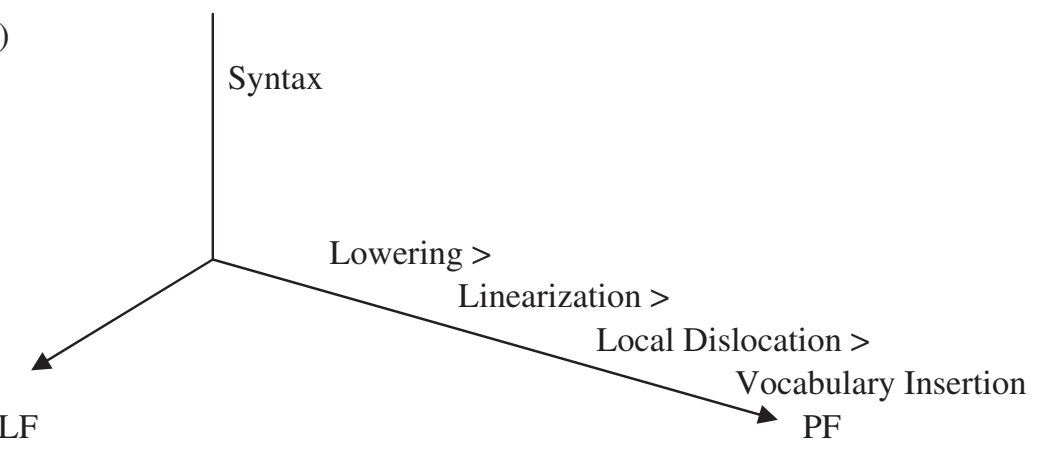

This particular view on morphological displacement would be further supported if these locality conditions do not only hold when it comes to morphological movement/affixation but also beyond them: deletion/ ellipsis appears to be an interesting domain to explore their existence. Detecting the working of the above mentioned locality conditions in this domain can provide further support for them being part of the language design.

Following Saab (2008) we adopt the view that there is indeed evidence for locality conditions of the above sort being at work in the domain of ellipsis, and that one is warranted to take ellipsis to be an operation that marks a given phrase or head as not subject to Vocabulary Insertion. In this we follow, among others, Bartos (2000a, 2001a), Kornfeld \& Saab (2004), Aelbrecht (2009), and Nunes \& Zocca (2009).

In this view, ellipsis can apply either in the syntactic component or in the PF component, i.e. Morphology. For the first type, the domain of application is a phrase, for the latter, the elided object is a Morphological Word (MW). The latter type of ellipsis, which we call Head or Morphological Ellipsis (see 14 below) proceeds under the same conditions as Morphological Merger, i.e. under immediate locality or adjacency. As we mentioned, like in the case of Morphological Merger, the objects that are susceptible to PF ellipsis are heads or, more precisely, Morphosyntactic Words. ${ }^{8}$

\footnotetext{
${ }^{8}$ However, unlike some instances of Morphological Merger, Subwords cannot be affected by Head Ellipsis. See Saab (2008) for detailed discussion.
} 


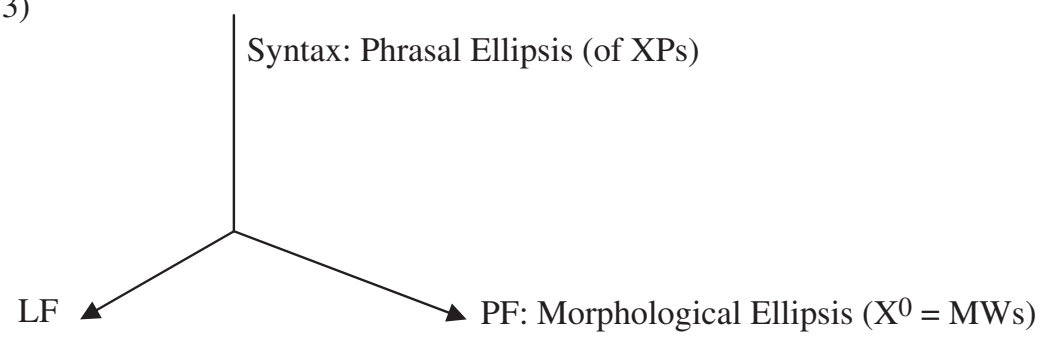

(14) Morphological Ellipsis: at PF, a morphosyntactic word (MWd) $\mathrm{X}^{0}$ can be elided only if $\mathrm{X}^{0}$ has an identical antecedent contained in a $\mathrm{MWd} \mathrm{Y}^{0}$ adjacent or immediately local to $\mathrm{X}^{0}$.

Similarly to Morphological Merger, the locality conditions on Morphological Ellipsis depend on Linearization. Thus, whereas immediate locality makes reference to syntactic hierarchies (i.e., it is the relation between a head and the head of its complement), adjacency is relevant only to precedence relations after Linearization has taken place.

As shown by Saab (2008), this approach to ellipsis phenomena predicts a set of intrincate interactions between phrasal and head ellipsis and, more generally, between syntax and morphology. A crucial piece of evidence involves the interaction between head movement and syntactic ellipsis. As shown in the abstract tree in (15), head movement automatically creates head ellipsis at PF via immediate locality, for the simple reason that adjunction of $\mathrm{Y}^{0}$ to $\mathrm{X}^{0}$ leaves lower $\mathrm{Y}^{0}$ with its antecedent copy contained in a head (i.e., $\mathrm{X}^{0}$ ) which is immediately local to the lower copy of $\mathrm{Y}^{0}$. We might conclude then that head copies are elided at PF via immediate locality, the same condition affecting Lowering in English:

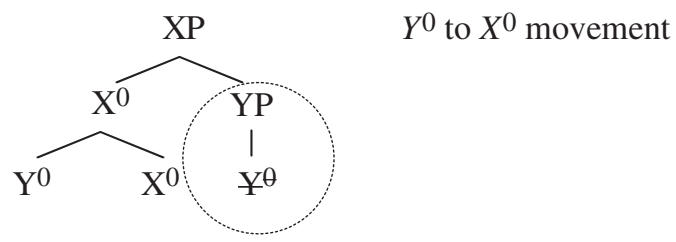

${ }^{9}$ Associated definitions ((ii) and (iii) from Embick and Noyer 2001: 574)

(i) The domain of $\mathrm{X}^{0}, \mathrm{X}^{0}$ a $\mathrm{MWd}$, is the set of terminal nodes reflexively contained in $\mathrm{X}^{0}$.

(ii) Morphosyntactic word: At the input to Morphology, a node $\mathrm{X}^{0}$ is (by definition) a morphosyntactic word (MWd) iff $\mathrm{X}^{0}$ is the highest segment of an $\mathrm{X}^{0}$ not contained in another $\mathrm{X}^{0}$.

(iii) Subword: A node $\mathrm{X}^{0}$ is a subword ( $\left.\mathrm{SWd}\right)$ if $\mathrm{X}^{0}$ is a terminal node and not an MWd. 
Now, if VP ellipsis is a syntactic or LF phenomenon, then, it follows that ellipsis of head copies cannot feed syntactic VP ellipsis. In this regard, the well-known fact that traces/copies of head movement have to be identical to their correlate traces/copies in the antecedent is accounted for. The following example from Goldberg (2005) illustrates this relation between ellipsis and head movement in Hebrew: ${ }^{10}$

$$
\begin{aligned}
& \text { Q: (Ha'im) Miryam hevi'a } \quad \text { Miryam bring-PAST-3SG-F ACC Dvora to-the-store } \\
& \text { Q '(Did) Miryam bring Dvora to the store?' } \\
& \text { Ai: Ken, hi hevi'a. } \\
& \text { yes she bring-PAST-3SG-F } \\
& \text { 'Yes, she brought [Dvora to the store].' } \\
& \text { Aii: *Ken, hi lakxa. } \\
& \text { yes she take-PAST-3SG-F } \\
& \text { 'Yes, she took [Dvora to the store].' (Goldberg 2005:160) }
\end{aligned}
$$

In (16), the only legitimate VP ellipsis answer is (Ai), where the verb in the antecedent and the stranded verb in the elliptical gap are identical. If heads are elided at PF, then the facts in (16) follow irrespectively whether head movement is syntactic or not. The crucial step in this argument is that head ellipsis, being a PF phenomenon, cannot feed syntactic ellipsis. See Saab (2008) for extensive discussion on this topic.

In what follows, we explore this particular view on ellipsis and its interaction with morphological deletion/movement. In particular, we inquire how syntactic ellipsis (i.e., phrasal ellipsis) interacts with Morphology in such a way as to produce 'government/licensing effects' in the domain of nominal ellipsis. As we will show, it will turn out that such effects are epiphenomena resulting from the syntax-morphology connection.

\section{The ellipsis-morphology generalization}

As the first step towards an explanation of the role of inflection in NPE, we follow Saab (2008), Faß (2008), Schoorlemmer \& Temmerman (2010,

\footnotetext{
${ }^{10}$ As is well-known, traces of phrases are "invisible" for the identity condition:

(i) John has three books by Chomsky but I do not how many books by Kayne fæf John has < how many books by Kayne>?.
}

This follows from the ellipsis typology in (13): phrasal copies are elided at syntax and, consequently, can feed other types of phrasal ellipses, such as sluicing in (i). Of course, ellipsis does not render the elliptical constituent invisible for LF computation. This indicates that ellipsis is just the name for an operation that marks a given phrase or head as not subject to Vocabulary Insertion (see section 3). 
2012), Stjepanović (2011) and Temmerman (2012) in assuming that ellipsis can bleed morphological processes. We phrase this as the following generalization. ${ }^{11}$

(17) Ellipsis-Morphology (Elmo) Generalization

For every morphological operation MO that affects the domain of $\mathrm{X}$, where $\mathrm{X}$ contains the target of MO, MO cannot apply in $\mathrm{X}$ if $\mathrm{X}$ is subject to ellipsis.

In the Distributed Morphology framework that we are using here and that we described above in section 2.2., (17) is predicted to apply if ellipsis is phonological non-insertion, i.e. the Elmo predicts the blocking of the lexical insertion rules that apply late in the PF-component of the grammar. Indeed, as an important consequence for the architecture of the grammar, (17) not only blocks vocabulary insertion rules, but also other PF-operations such as Morphological Merger. The theoretical consequence of such an empirical observation is that ellipsis should apply before spell-out or at the spell-out point but before morphological operations. In others words, as argued in the previous section (see 13), phrasal ellipsis could be conceived as a part of the narrow syntax, a revealing conclusion, if correct.

Following the above mentioned literature, we adopt (17) as our working hypothesis and we dedicate the rest of the paper to provide novel evidence for it. In section 3.1. we support the Elmo generalization in the realm of the clausal domain (VP ellipsis), and in 3.2. we apply it in the nominal domain (NP ellipsis).

\subsection{The Elmo generalization in the verbal domain}

In the DM-framework, morphemes corresponding to affixes and lexical roots are represented by syntactic heads in the structural representation, and get combined via morphosyntactic operations (head movement or different types of morphogical displacements) in the syntactic and postsyntactic components. These operations work on morphosyntactic feature-bundles that are only spelled out as vocabulary items at the point of vocabulary insertion in the postsyntactic component.

A particularly relevant configuration we will refer to is the so-called "stranded affix filter configuration" (Lasnik 1981), which arises when an

${ }^{11}$ In earlier work, we formulated this as a lowering-raising asymmetry:

(i) Raising/lowering generalization on ellipsis

Descending (morphological) operations, but not raising ones, are blocked under ellipsis.

The choice between (17) and (i) depends on assumptions about the nature of head movement or concord, namely whether these are morphological operations or syntactic ones. Since we do not discuss these issues and stick only to illustrate (17) in the realm of morphological displacement, we adopt (17) in the remainder of this paper. 
affix is severed from its morphological host via some means, such as ellipsis. Stranded affixes cannot survive on their own and need to be rescued by some operation that provides them with another possible host. Following the gist (but not the letter) of Embick and Noyer (2001), we take English $d o$-support to exemplify such a rescue operation. In finite clauses in English, $v$ does not move to $\mathrm{T}$, yet $\mathrm{T}$ spells out on $v$ morphologically via an operation of lowering (Embick \& Noyer 2001, p 586):

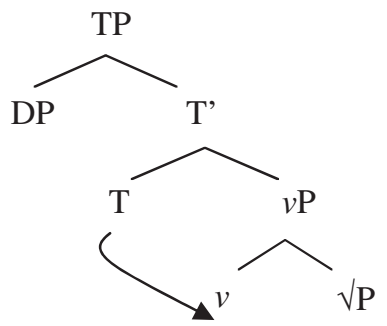

As noticed in section 2.2., the lowering operation that takes place before vocabulary insertion has to operate under immediate locality, defined as a relation between a head and the head of its complement. Adjacency is not required between $\mathrm{T}$ and $v$, as is evident from the fact that adverbs can intervene between the subject and the spell-out of the lowered tense (see 10 repetead as 19; see also Bobaljik 1995):

(19) John [ ${ }_{\mathrm{TP}} t\left[{ }_{\mathrm{v} \mathrm{P}}\right.$ completely [ ${ }_{\mathrm{pP}}$ destroy-ed the opposition ]]]

Lowering can only be successful when the $v$ head is immediately local to the $\mathrm{T}$ head, but cannot take place if $\nu \mathrm{P}$ is not in the complement position of $\mathrm{T}$, due to movement of the $\mathrm{VP}$, or $\mathrm{T}$-to-C movement taking $\mathrm{T}$ into a higher position:

(20) a. John wanted to call Mary, and eventually call Mary he did.

b. Does John like Mary?

c. What did you buy?

In these cases, something has to rescue the stranded affix, and this is done via $d o$-support, which spells out the finite tense (although it is important to note that $d o$-support is not solely a morphophonological rescue operation for Embick \& Noyer (2001), who take do to be the realization of a default $v$ inserted on $\mathrm{T}$ and spelled out there as $d o$ ). What matters for our purposes is that the exact same rescue mechanism that takes care of the stranded $\mathrm{T}$ affix in (20) is also applied in case $\mathrm{T}$ gets stranded when the $v \mathrm{P}$ is missing due to ellipsis of the $v \mathrm{P}$ (Lasnik 1999): 
(21) a. I went to the cinema and Mary did [go to the cinema], too.

b. TP
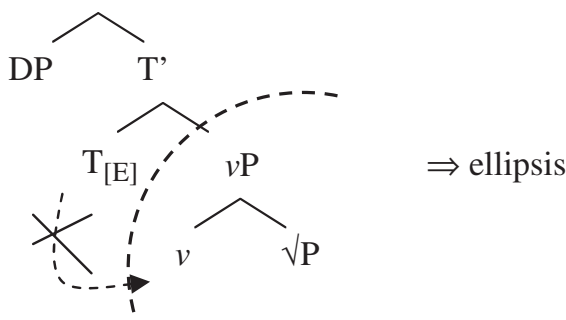

In short, VP ellipsis with stranded $\mathrm{T}$ in English falls under the Elmo.

Note that in contradistinction to head lowering operations, head raising out of the elliptical gap can be attested in the verbal domain. In languages in which the verb raises out of the VP in overt syntax, ellipsis can target the VP to the exclusion of the raised verb, cf. (22). Goldberg (2005), who studied the existence of this type of ellipsis configuration, dubbed this construction $V$-stranding VP-ellipsis (where $\mathrm{V}$ in 22 stands for $v+\sqrt{ })$ :

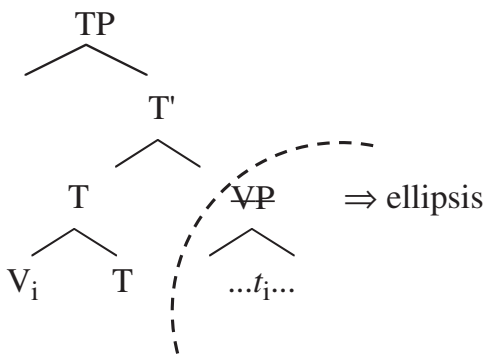

For illustration, consider the following piece of data from Portuguese, where the verb pôs is interpreted as pôs os óculos na mesa 'put the glasses on the table', i.e., the verb plus all its complements (Cyrino \& Matos 2002:6; see also the Hebrew example in 16):

(23) Quando a Ana pôs os óculos na mesa, a Maria when the Ana put the glasses on the table the Maria também pôs ${ }_{i}\left[{ }_{v p} t_{i}\right.$ es óculos na mesa]. too put

'When Ana put the glaces on the table, Maria did too.'

After this introduction of the generalization on the ellipsis-morphology connection, we move on to show how stranded affix filter configurations arise in the nominal domain when ellipsis applies to an NP projection. Before turning to illustration of this claim, we briefly introduce NP ellipsis and spell out our assumptions about the structure of DPs. 


\subsection{The Elmo generalization in the nominal domain}

For our analysis in subsequent sections, we adopt a minimal and highly uncontroversial structure of DPs as in (24), in which features pertaining to number are universally encoded in an independent functional head Num above the $n \mathrm{P}$ (Ritter 1991 and much subsequent work). As for the $n \mathrm{P}$ domain, we assume that it minimally consists of a lexical Root, $\sqrt{ }$, and a category-defining head, $n$, and that both heads are combined via head movement in the syntax (for a related proposal in the nominal domain, see Alexiadou 2001, and subsequent works).

$$
\begin{aligned}
& \text { [DP D [NumP [AP] Num }\left[{ }_{n \mathrm{P}}[\mathrm{AP}]{ }_{n \mathrm{P}} \sqrt{ }+n_{\text {[gender }]}[{ } \mathrm{P}\right. \\
& \left.\left.\left.\left.t_{\sqrt{ }}[\mathrm{AP} / \mathrm{PP}]\right]\right]\right]\right]
\end{aligned}
$$

We take adjectival modifiers to be phrasal adjuncts (or specifiers) that attach to the $n \mathrm{P}$ or above and $\mathrm{AP} / \mathrm{PP}$ complements of the noun to be selected by the Root. Gender features, when present in a language, are encoded inside the $n \mathrm{P}$ (cf. section 5 for a representation of gender in Spanish).

We also subscribe to the view that the noun head does not undergo head movement in the syntax to $\mathrm{Num}^{0}$ or $\mathrm{D}^{0}$ (see Cinque 2010 for a similar view). In Lipták and Saab (2014) we provide evidence against Nraising (where $\mathrm{N}$ stands for $n+\sqrt{ }$ ) from the domain of NP ellipsis and the existing possibility of raising heads out of ellipsis sites in general. The argument is based on the empirical observation that the equivalent of $\mathrm{V}$ stranding VP-ellipsis we illustrated in (23) does not exist in the nominal domain of languages in which N-to-Num or N-to-D movements have been argued to take place, such as Spanish (Picallo 1991 and Bosque \& Picallo 1996).

(25) Juan habló con tres estudiantes de física y yo hablé Juan talked with three students of physics and I talked con dos estudiantes. with two students

'Juan talked to three students of physics and I talked to two students.'

Unlike (23), where the second clause is necessarily understood as put the glasses on the table, in (25) the nominal dos estudiantes cannot be interpreted as dos estudiantes de física, but only as students of some unspecified discipline. Given that Spanish NPs can be elided (more on this in section 5), the reason for the lack of the reading two students of physics can only be the fact that the noun does not raise to Num, and thus the configuration that could give rise to $\mathrm{N}$-stranding NP ellipsis cannot ensue. In other words, NP ellipsis constructions in the nominal domain as the one in (26) parallel languages like English (21a) in the sentential domain and not like Portuguese (23) or Hebrew (16): 
(26) Juan habló con tres estudiantes de física y yo hablé Juan talked with three students of physics and I talked con dos estudiantes de físiea. with two students of physies

'Juan talked to three students of physics and I talked to two.'

This in turn also entails that the noun cannot pick up inflectional morphology as a result of syntactic merger (i.e. head movement) to $\mathrm{Num}^{0}$ or $\mathrm{D}^{0}$ in overt syntax. In the DM-framework, this means that the inflectional morpheme corresponding to number has to combine with the noun via other operations, for example an operation of morphological merger such as Lowering:

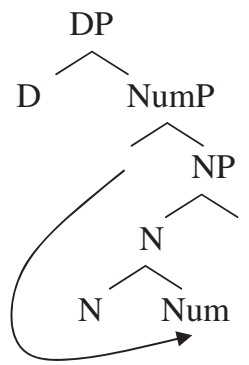

If it is indeed Lowering that unites number and the noun in some languages, we make a prediction for these languages in the light of the generalization in (17): if the host of lowering, the $n$ head, is not immediately local to the Num head, lowering cannot proceed and results in a stranded affix filter configuration. Similar to English VP ellipsis, this can happen when the NP undergoes ellipsis:

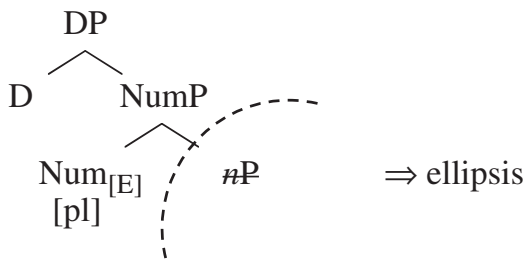

When NP ellipsis happens, the affix spelling out Num gets stranded and cannot surface on its own. The question is: what do languages do to rescue the stranded number affix? In the next section, we provide a case study on agglutinative languages where this is done via alternative means of Morphological Merger. In section 5, in turn, we show how Spanish circumvents the problem via Morphological Ellipsis.

Before proceeding, however, we need to stress the metaphorical use of term 'rescue' here (mentioned already in section 1), as we adhere to the widely accepted view that grammatical operations (both syntactic 
or morphological) apply 'blindly'. In this view, syntactic ellipsis (ellipsis of a phrase) takes place blind to the eventual morphological output. In other words, selection by an [E] feature triggers ellipsis of the complement of the head enconding such a feature in the syntax (maybe, by marking the complement as subject to non-pronunciation at PF; Saab 2008), regardless of the morphological output obtained after ellipsis applies. The output that ellipsis produces can feed certain operations after syntax, such as Morphological Merger or deletion, the choice made by parametric properties and language-particular constraints. $^{12}$

\section{Rescue by Morphological Merger: A case study on Hungarian}

\subsection{The base structure of Hungarian DPs}

Simple (unpossessed) Hungarian DPs have the base order: Determiner Numeral/Quantifier - Adjective - Noun. Adjective modifiers can only occur to the left of nouns and arguments to adjectives always precede the adjective selecting them:
a. a három új ház the three new house 'the three new houses'
b. a fiára büszke apa
the son-POSS3SG.ON proud father
'the father proud of his son'

The determiner, numeral/quantifier and the adjective are not inflected, and show no agreement for number or case (Hungarian lacks gender). Number and case are marked on the noun only. Singular number is morphologically unmarked, and must be used also in cases in which a numeral or the quantificational item specifies plurality for the whole phrase (see 29a above). The plural is marked with $-k$ in non-possessed noun phrases and with $-i-$ in possessed ones. The plural morpheme in non-possessed nouns has five allomorphs: $-k,-o k,-a k,-e k,-\ddot{o} k$, depending on the quality of the final vowel or consonant of the noun. Importantly for our purposes, marking plural both on the adjective and

\footnotetext{
${ }^{12}$ For this reason, ellipsis is incapable of targetting a larger phrase than $n \mathrm{P}$ (e.g. NumP) in order to prevent a stranded affix configuration at PF. This kind of 'fixing' of the problem is impossible as the application of phrasal ellipsis is insensitive to the final output. If it was not, we would not find languages such as English, where $v \mathrm{P}$ ellipsis, which results in a stranded affix violation, exists alongside TP ellipsis, which does not. In the Spanish nominal domain we also have a similar situation: as we will see in section 5.1, Spanish allows both NumP ellipsis and $n \mathrm{P}$ ellipsis and only the second one gives rise to a stranded affix violation. The fact that NumP ellipsis does not apply to prevent the resulting output of $n \mathrm{P}$ ellipsis demonstrates that phrasal ellipsis is a syntactic phenomenon, blind to mophological outputs. Thanks to an anonymous reviewer for raising this point.
} 
the noun is illicit (30b) and so is plural marking on the adjective only (30c):

(30) a. az új ház-ak

the new house-PL

b. *az új-ak ház-ak

the new-PL house-PL

c. *az új-ak ház

the new-PL house

'the new houses'

As for the structural representation of Hungarian DPs, we follow the mainstream accounts that assume a left branching functional domain in the DP (including KP for case) such as É. Kiss (2002) or Dékány (2011), and the analysis of Bartos (2000b) for the specifics of morpheme composition in this domain. We take the noun to occupy its base position in the $n \mathrm{P}$ - indeed, there is no reason to assume that the noun leaves its $n \mathrm{P}$, as no adjective, number or determiner can ever follow a noun in a nominal constituent in Hungarian, the noun is strictly the last element of the DP. We assign adjectival phrases the role of modifiers that can attach to $n \mathrm{P}$ or NumP and we account for the spell-out of plural morphology on the noun by assuming lowering of Num to $\mathrm{N}$ (Bartos refers to the latter operation as 'morphosyntactic merger'):
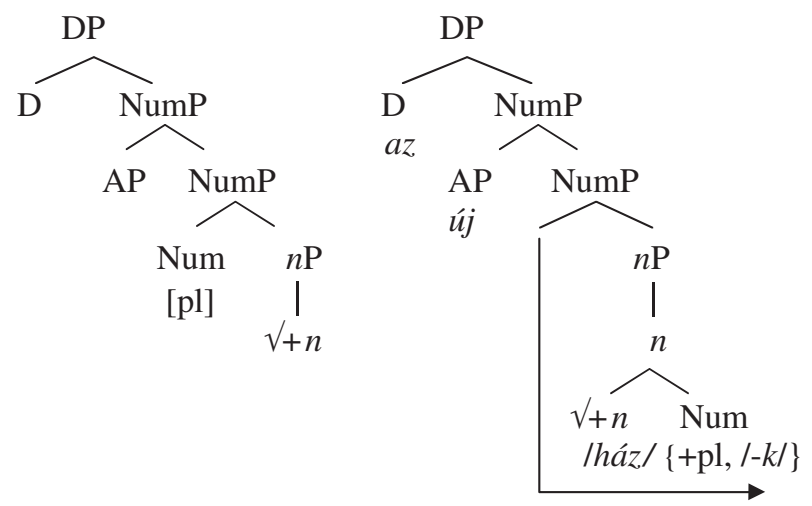


\section{Andrés Saab \& Anikó Lipták}

\subsection{NP ellipsis in Hungarian}

$n$ Ps can be elided in Hungarian, similarly to many languages, in contexts where the $n \mathrm{P}$ has a suitable (linguistic or non-linguistic) antecedent. What can be missing in cases of $n \mathrm{P}$ ellipsis is the noun or the noun together with one or more adjectival modifier. What gets stranded as a result of ellipsis is thus a determiner plus a numeral/quantifier and/or an adjectival modifier. In the following examples, we underline the part of the antecedent which is understood to be missing in the elliptical gaps indicated by [_]

(32) Mari a régi kis ház-ak-at látta. Én az új

Mari the old all house-PL-ACC saw I the new nagy-[_]*(-ok-at)

big-PL-ACC

'Mari saw the old small houses. I saw the new big ones.'

(33) Mari a régi kis ház-ak-at látta. Én az új-[_] $]^{*}(-a k-a t)$.

Mari the old all house-PL-ACC saw I the new-PL-ACC

'Mari saw the old small houses. I saw the new (small) ones.'

(34) Mari egy ház-Ø-at látott. Én négy-[_]*(-Ø-et).

Mari one house-ACC saw I four-SG-ACC

'Mari saw one house and I saw four ones.'

(35) Én a János mellett-i szék-Ø-en ültem. Ök a Péter

I the János next-ADJ chair-SG-LOC sat they a Péter mellet-i-[_] $]^{*}($-ek-en). next-ADJ-PL-LOC

'I sat on the chair next to János. They on the ones next to Péter.'

As can be observed in these examples (note the glosses), when the noun is elided, number (as well as case) is obligatorily spelled out on the linearly last remnant preceding the elliptical gap (Kenesei et al 1998, p. 92, 187, 
331, see also Laczkó 2007, Dékány 2011, to appear). ${ }^{13}$ It is also important to notice that the number specification of the elliptical DP need not be identical to that of the antecedent DP. We provide an example where this is not the case in (36):

13 Possessed nouns phrases are exceptional in this respect: they do not allow for this pattern of spelling out the nominal affixes (or any subset of them) on the linearly last remnant (Kenesei et al 1998) — contrary to the claim in Laczkó (2007).
(i) a. a ti
érdekes könyv-e-i-tek
b. * a ti
érdekes-[_]-e-i-tek
the you. PL interesting book-POSS-PL-2PL
the you.PL interesting-POSS-PL-2PL
'your(PL) interesting books'
'your(PL) interesting ones'

To understand this difference between possessed an non-possessed NPs, note that in possessed noun phrases NumP builds in between two functional projections dedicated to marking the possessive relation: the possessor agreement projection (Poss2P) and possessedness projection (PossP) in the order indicated in (i) (labels adopted from Dékány to appear):

(ii) $\left[\mathrm{DP}\left[\mathrm{Poss} 2 \mathrm{P}\left[\mathrm{NumP}\left[\mathrm{PossP}\left[{ }_{n} \mathrm{P}\right]\right]\right]\right]\right.$

When flanked by the possessedness and the agreement affix, Num is spelled out as the invariant $-i$ - infix (cf. (i) above), an allomorph of the $-k$ plural morpheme.

We believe that the ungrammaticality of (ib) stems from the fact that the Poss head cannot license ellipsis of its complement. Rather, as the literature on possessives unanimously points out, anaphoric possessives contain a nominal pro-from (Bartos 2000b, Laczkó 2007, Dékány 2011, to appear). Indication that the pro-form is different from NP ellipsis comes from the obligatory presence of an -é affix, which uniquely marks anaphoric possessives, and which blocks the appearance of the noun and the Poss affix, as well as any modifier that the noun might have:

(iii) a ti-é-i-tek

the you.PL-é-PL-2PL

'your(PL) ones'

While the treatment of the -é suffix is not uniform in the works cited (Bartos 2000b equates it with the Poss head, Laczkó 2007 with the pro-form and Bartos 2001b, Dékány to appear with genitive case), it is clear that the pro-form must correspond to at least the Poss' node in size or to the entire PossP, if possessors are not taken to be generated in Spec,PossP. We thus contend that the presence of the anaphoric pro-form that is bigger than NP in possessive constructions entails that NP ellipsis can never take place in possessives to begin with (see Dékány to appear for a similar argument), and this is what results in the lack of well-formedness in (ib).

Note before closing that data like (iv) (provided by an anonymous reviewer) need not be taken as counter-evidence to our claim that ellipsis cannot affect any portion of a possessed noun phrase:

(iv) Péter a régi könyv-e-i-m-et kérte el, Laci az új-[_]-ak-at.

Péter the old book-POSS-PL-1SG-ACC asked PV Laci the new-PL-ACC

'Péter asked out my old books, and Laci the new books / the new books of mine.'

As the translation shows, the missing nominal in these constructions can be interpreted either as non-possessed or as possessed, and one might be inclined to treat the latter as the result of ellipsis of the entire possessed nominal phrase. We believe, however, that the possessed reading of the missing noun is not a result of ellipsis, but is due to pragmatic inference. Evidence for such an inference comes from languages where a noun phrase can receive the interpretation of a possessed noun phrase even though its syntax is incompatible with the expression of possession. Consider English for example, where the definite article and a possessor are in complementary distribution in DPs, yet John asked for my new books, and Bill for the new ones allows for a possessive reading in the second conjunct. 
(36) Mari a régi ház-ak-at látta. Én az új-[__*(-Ø-at).

Mari the old use-PL-ACC saw I the new-SG-ACC

'Mari saw the old small houses. I saw the new one / *ones.'

The fact that number specification on the elliptical DP is not necessarily identical to that of the antecedent DP provides first-hand evidence that $\mathrm{NP}$ ellipsis is elision of an $n \mathrm{P}$, and nothing bigger: NumP cannot be deleted. If NumP was deleted together with the noun, it would need to be identical as well (i.e. specified in the antecedent) and we would not expect cases where number can vary. Lack of number-invariance dovetails well with the observation we have made above, namely that even though the host of number morphology, the noun, is missing in cases of NP ellipsis, number morphology nevertheless survives in elliptical DPs on the adjective or numeral that shows up as the linearly last element in the DP. These two observations on the morphological realization and the meaning of the elided phrase suggest that Hungarian NP ellipsis is capable of eliding an $n \mathrm{P}$, possibly modified by adjectives, but not NumP. ${ }^{14}$

\subsection{The morphosyntax of Hungarian NP ellipsis}

Having established that the examples in (32-36) are cases of NP ellipsis and not of NumP ellipsis, we can move on and examine the morphosyntax of the elliptical DPs. As was observed above in (32-33), repeated here, a key property of elliptical DPs in Hungarian is that the inflectional morphology belonging to the noun gets preserved and spelled out on the last remnant of the elliptical DP:

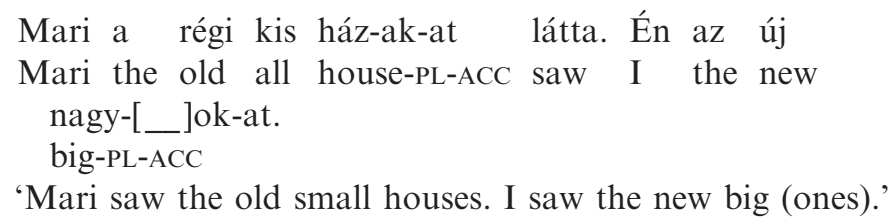

\footnotetext{
${ }^{14}$ Note that the above described phenomenon also occurs in cases in which the remnant adjectival modifier is a complex, phrasal, expression. Consider for illustration passive participle clauses, which are analyzed in current literature as containing an entire clause, complete with an internal argument as well as a phonetically null PRO subject (É. Kiss 2002). Confer the non-elliptical cases in (i) and the elliptical ones in (ii):

(i) a János által megold-ott feladatok the János by solve-PPRT problems 'the problems solved by János'

(ii) A Mari által megoldott feladatokat láttam. A János által megoldott-[_] ]-ak-at the Mari by solved problems-ACC saw-1SG the J. by solved.PL.ACC még nem. yet not

'I have seen the problems solved by Mari. I haven’t (seen) the ones solved by János.'
} 
(38) Mari a régi kis ház-ak-at látta. * Én az új-ak-at

Mari the old all house-PL-ACC saw I the new-PL-ACC nagy [_].

big

'Mari saw the old small houses. I saw the new (small ones).'

Concentrating on the spell-out of number morphology only, ${ }^{15}$ let us consider why the plural affix shows up on the last remant. In section 4.1., number morphology has been said to be the result of lowering Num onto $n$ in non-elliptical Hungarian DPs. If, however, the noun is elliptical, lowering is blocked as predicted by the Elmo generalization, since there survives no instance of a noun onto which the number morphology can be glued in PF.

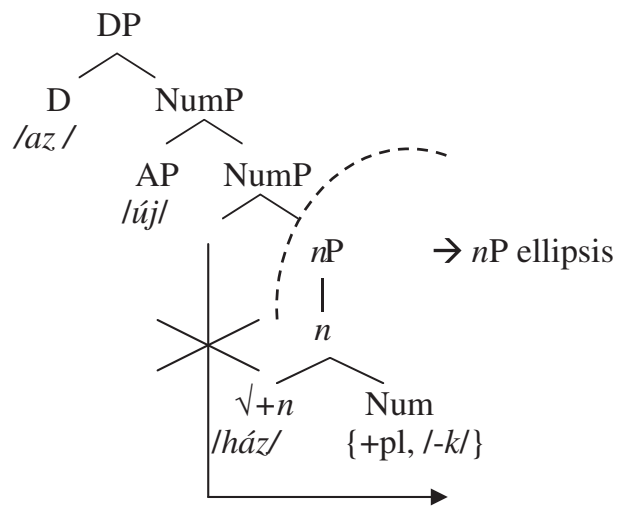

The resulting configuration is a stranded affix configuration: the stranded number affix needs to look for a suitable host. We argue that it will be hosted by material that precedes the elliptical noun in the DP: an adjectival phrase as in (37). For the placement of adjectives, we assume that they can optionally adjoin to either NumP or $n \mathrm{P}$ in general. ${ }^{16}$ What is important is that at the point of vocabulary insertion, the adjective and the number morpheme will be linearly adjacent and the number

\footnotetext{
${ }^{15}$ Case affixes behave exactly like number ones in the contexts of nominal ellipsis, as the reader can see in examples like (32-37): the case morpheme always ends up on the exponent that bears the number marker as well. How exactly the number and the case affixes end up being adjacent to each other in this way in Hungarian (as well as in Quechua and Turkish, see below), we put aside for the purposes of this paper. See McFadden (2002) for an account in which case is placed in the postsyntactic component.

${ }^{16}$ Note that with respect to numerals, we assume that they are in a projection higher than NumP, in a functional category that we refer to as NumeralP, following Cheng and Sybesma (2005):
}

(i) Mari a régi ház-ak-at látta. Én a három új [_]-Ø-at.

Mari the old house-PL-ACC saw I the three new-SG-ACC

'Mari saw the old houses. I saw the three new ones.' 
morpheme can undergo Local Dislocation, which is defined as follows (see also section 2.2).

(40) Postsyntactic movement under adjacency (Local Dislocation) is defined structurally in terms of concatenation statements. Formally, the operation is one of adjunction under adjacency.

(Embick 2007:323)

The type of Local Dislocation that the plural morpheme undergoes is string vacuous local dislocation, which we will refer to as leaning in this article (see Embick \& Noyer 2001). The plural affix leans onto the adjacent adjective to its left.

$$
\begin{aligned}
& \text { LINEARIZATION } \rightarrow \text { LEANING } \rightarrow \text { PHONOLOGICAL SPELL-OUT } \\
& u j *^{*}-k \quad u j j-k \quad \text { ujjak }
\end{aligned}
$$

Via leaning, the stranded affix finds a suitable host for itself and spells out as plural on the adjectival remnant. Assuming a process like leaning accounts for the strict locality between the host and the number affix. If the relation was not established at linear structures, we would assume that plural morphology need not be sitting on the last remnant in the DP but could occur on any of the remants when there are many. This is never found, however, as (37/38) demonstrate: the plural marker can only be found on the linearly last adjectival remnant.

In sum, this section has shown that NP ellipsis exists in Hungarian, and when this process strands an adjectival remnant, the number marking that normally appears on the noun appears on the last adjectival remnant. We have argued that this is the result of the number affix being stranded in ellipsis, and being 'saved' by the linearly last remnant adjective via Local Dislocation.

\subsection{Similar phenomena in other languages}

Before closing this section, it is important to point out that the above postulated mechanism is by no means unique to Hungarian. It can also be found among languages that are usually characterized in the typological literature as agglutinative, such as Persian (see the study of Ghaniabadi 2010 dedicated to this phenomenon), Quechua or Turkish, as well as Northern Sámi (Kester 1996b, cited in Dékány 2011). We demonstrate this for Quechua and Turkish.

For Quechua, evidence for the same behaviour comes from Weber's (1983) grammar of the language, cf. the rule in (42) describing data such as (43) from Ayacucho Quechua (Willem Adelaar p.c.), and (44) from Imbabura Quechua (Cole 1982): 
(42) Shift of transparent head's suffixes (Weber 1983, p. 47)

If a modified head is for some reason absent, the suffixes which it has (except those internal to its own composition) are attached to the most immediately preceding word of the modifying phrase.
a. Ñuqa yuraq wasi-kuna-ta-m riku-ni, qam-ñataq
I white house-PL-ACC-VALID see-1SG you-PRT yana-kuna-ta-m.
black-PL-ACC-VALID

'I see white houses, you on the other hand black ones.'

b. Nuqa yuraq wasi-ta-m riku-ni, qam-ñataq

I white house-ACC-VALID see-1SG you-PRT yama-kuna-ta-m.

black-PL-ACC-VALID

'I see a white house, you on the other hand black ones.'

(44) a. Juzi jatun wasi-ta-mi chari-n.

Jose big house-ACC-VALID have-3

'Jose has a big house.'

b. Juzi jatun-ta-mi chari-n.

Jose big-ACC-VALID have-3

'Jose has a big one.'

As Weber's formulation mentions, locality in the spell out of noun morphology under ellipsis is observed in Quechua just as in Hungarian: morphemes have to attach to the immediately preceding modifier in the DP. We believe these data in Quechua should be handled in a manner parallel to the facts of Hungarian. In contexts of NPE, the noun does not get inserted. Putting aside case and evidential morphemes, (43b) would give rise to the following stranded affix configuration:

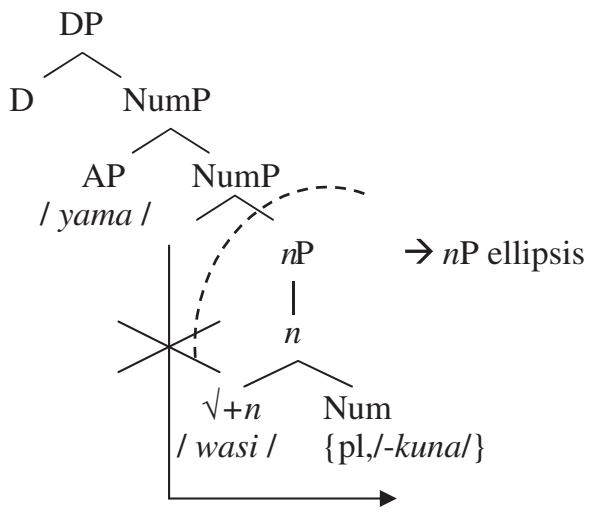

Turkish can also be shown to provide evidence for the same mechanism (Saab 2008). Word order inside the DP in Turkish is similar to 
Hungarian: the noun head precedes number morphemes, which in turn precede the possessive. In final word position case morphemes occur: ${ }^{17}$

$$
\text { N - NUM - POSS - CASE }
$$

A simple example that illustrates each of these categories is the following (Hankamer 2005:1):

(47) uCar-lar-ImIz- da

plane-PL-POSS.1PL-LOC

'in our planes'

Turkish makes productive use of nominal ellipsis. For instance, (48b) can only be interpreted as the book on the shelf if there is a previously mentioned antecedent in the linguistic context; i.e. the locative raftaki ['on the shelf'] is a modifier of kitap ['book']:
a. raf-ta-ki kitap
shelf-LOC-KI book
b. raf-ta-ki
'the book on the shelf'
shelf-LOC-KI
'the one on the shelf'

(Hankamer 2005:3)

Hankamer (2005) analyzes (48b) as a case of nominalization triggered by the $-k i$ suffix. It is plausible, however, to think of these cases as true instances of nominal ellipsis. Indeed, Turkish seems to have real cases of nominal ellipsis on the one hand, and cases of null noun constructions on the other. A phrase such as the following is ambiguous in the appropriate context:

(49) ev-de-ki-ler-imiz

home-LOC-KI-PL-POSS.1P

'those of us who are at home'

(Hankamer 2005:4)

In an out of the blue context, (49) corresponds to a [+human] null construction; nevertheless, in a context where kitap ['book'] has been mentioned, (49) can also be interpreted as our books that are in our houses with the noun omitted. More examples are provided below:
a. ev-imiz-de-ki
kitap-lar-ImIz
home-POSS.1PL-LOC-KI book-PL-POSS.1PL
'our books that are in our houses'
b. evimizdekilerimiz
reading A: 'ours that are in our houses'
reading B: 'those of us who are in our houses'

(51) a. Ankara'-da-ki ev-ler-imiz

Ankara'-LOC-KI home-PL-POSS.1PL

'our houses that are in Ankara'

\footnotetext{
${ }^{17}$ All the data are from Hankamer (2005 and p.c.), to whom the first author is especially grateful.
} 
b. Ankara'dakilerimiz

reading A: 'ours that are in Ankara'

reading B: 'those of us who are in Ankara'

The DPs in (50b) in (51b) are interpreted either in relation to an antecedent noun or as [+human] empty nouns. The two simplified underlying structures for (50b) are as follows:

(52) a. evimizdeki kitaplerimiz

b. evimizdeki $n_{[+ \text {human] }}$ lerimiz

(52a) corresponds to a real case of nominal ellipsis, where the noun kitap has been elided under identity with an antecedent noun in the linguistic context. In turn, (52b) is a construction involving an empty noun, where the human interpretation is a property of the $n$ involved in the DP at hand (see Saab 2008, 2010 for more details on empty noun constructions of this type). We will focus then only on constructions like the one in (48b), repeated below:
a. raf-ta-ki kitap shelf-LOC-KI book
b. raf-ta-ki
'the book on the shelf'
shelf-LOC-KI
'the one on the shelf'

The main evidence in favor of this analysis comes from the fact that case and number morphemes, like in Hungarian, are excluded from the elliptical site. In effect, such as it can be observed in the examples (54b) and (55b), the plural marker ler and the case suffix (when there is one) are adjoined to the remnant (cf. Hankamer 2005:3):

$$
\begin{aligned}
& \text { a. arab-m-da-ki kiSi-ler } \\
& \text { car-POSS.1SG-LOC-KI person-PL } \\
& \text { 'the people in my car' }
\end{aligned}
$$

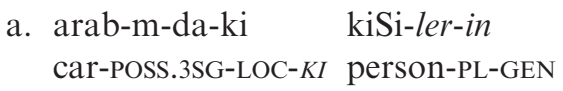

$$
\begin{aligned}
& \text { 'of the people in my car' }
\end{aligned}
$$

b. arab-m-da-ki-ler car-POSS.1SG-LOC-KI-PL 'the ones in my car'

Both the plural -ler and the genitive -in must be interpreted in relation to the elided noun $k i S i$ in each example. These data are particularly interesting because, as Hankamer (2005) points out, they show that $-k i$ is not only able to follow case, possessive (as in arab-m-da-ki) and plural morphemes, but it can also precede them, a problem for traditional analyses of morpheme ordering in Turkish. Evidently, the problem vanishes once it is assumed that the cases at hand involve nominal ellipsis and, more specifically, that the elliptical phrase in Turkish is just the $n \mathrm{P}$. Like in Hungarian, a post-syntactic mechanism adjoins the sequence formed by the number and case morphemes to the remnant of the elliptical gap under linear adjacency. In other words, the distribution of 
number morphology in Turkish also demonstrates the validity of the Elmo-generalization, where the stranded affix is rescued via morphological displacement.

\section{Rescue by deletion: the case of Spanish}

So far, we have seen how Morphological Merger and phrasal ellipsis interact with each other in order to obtain a legitimate PF output as far as number marking is concerned. In short, the number affix, which occurs adjoined to the $\mathrm{N}$ head in non-elliptical contexts, gets spelled out on another category whenever ellipsis deletes this $\mathrm{N}$ creating a putative violation of the stranded affix filter. Evidence seems to suggest that this type of displacement complies with the properties of post-syntactic movement, as originally defined in Embick and Noyer (2001) and Embick (2007). The main conclusion based on the facts explored in the previous section is that the Elmo-generalization we stated in section 3 applies quite generally in agglutinative languages with productive NP ellipsis.

In this section, we show that the same stranded affix configuration is obtained in NPE contexts in inflectional languages like Spanish. However, unlike the agglutivative language strategy we have explored, Spanish does not resort to any morphological merger, but to Morphological Ellipsis. As argued in section 2.2, Morphological Ellipsis is subjected to the very same locality conditions as Morphological Merger; i.e., immediate locality (Lowering) and adjacency (Local Dislocation).

Descriptively speaking, nominal ellipsis in Spanish requires the presence of a determiner that minimally expresses number overtly (cf. Kornfeld \& Saab 2004 and section 2.1. above). Compare for instance the following cases where only inflected cuál (es) 'which' or algun (os) 'some', as oppposed to invariable qué 'what' and cada 'each' respectively, license nominal ellipsis (adapted from Kornfeld \& Saab 2004:190).
a. ¿Qué/cuáles libros de Borges y *qué/cuáles libres what/which.PL books of Borges and *what/which.PL books de Bioy te gustan? of Bioy you like
'Which books of Borges and which of Bioy do you like?'
b. cada/algún estudiante de física y *ada/alguno each/some.sG student of physics and *each/some.sG estudiante de lingüística student of linguistics 'each/some student of physics and each/some of linguistics'

The correct generalization for Spanish is that the determiner, when present, must be inflected at least for number - gender morphology in itself is not enough. As discussed in Eguren (2010), the quantifier todo / 
toda 'all', a universal quantifier, inflects for gender but not for number (i.e., they are invariably singular; e.g. *todas nñas vs. toda niña 'every girl'). However, this inflectional feature does not allow for nominal ellipsis:

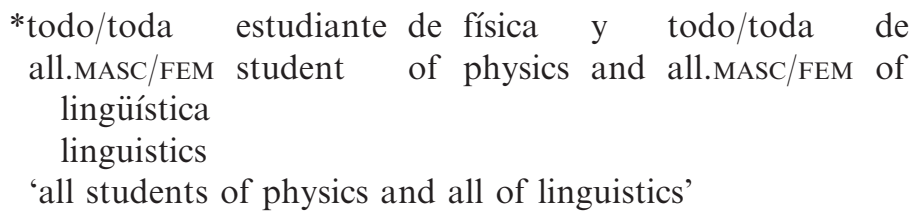

Examples like this have been taken as evidence against the idea that inflection plays a role in licensing ellipsis. For Spanish, this is the position adopted by Eguren (2010), who states that NPE only requires a contrast condition for surviving remnants (in consonance with approaches like Giannakidou \& Stavrou 1999, among others). We think that while the interaction between pragmatic-semantic factors and ellipsis cannot be denied, things are evidently more complex than such a reductionist move suggests (see footnote 5 above). Number agreement plays an important role in nominal ellipsis in Spanish. Before entering into the details of why this is the case, let us clarify the empirical domain we are exploring.

\subsection{The size of ellipsis in the nominal domain: $\mathrm{n} P$ vs NumP ellipsis}

As discussed in section 3.2., there is no N-to-Num raising in Spanish. We base this conclusion on the observation that if $\mathrm{N}$-to-Num raising was taking place, we would expect Spanish to allow for N-stranding NP ellipsis, contrary to the basic facts. Instead of assuming $\mathrm{N}$-raising, we assume that Num lowers to the $\mathrm{N}$ position, an operation subject to immediate locality, just like in Hungarian (see section 4). However, Spanish crucially differs from Hungarian in that it requires Concord, a post-syntactic operation of feature copying. ${ }^{18}$ As is well known, some modifiers and determiners in Spanish show gender and number agreement on the basis of the information present in the $n^{0}$ and $\mathrm{Num}^{0}$ heads, respectively (see Saab 2004, 2008 and 2010). We take Concord to be an operation that introduces dissociated morphemes at PF (in Embick \& Noyer's 2001 sense):

\footnotetext{
${ }^{18}$ However, the argument made in this section does not depend on the syntactic or morphological nature of Concord. We just follow Halle and Marantz's (1993) view on Concord as a morphological operation for expositive convenience.
} 
(58) morphological operations in the Spanish DP

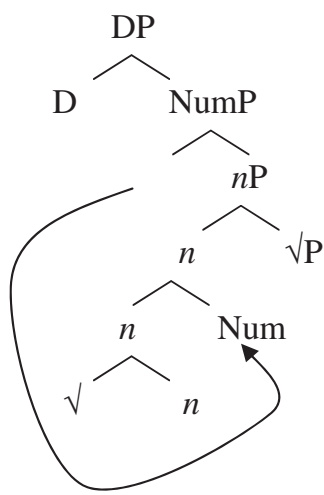

(i) lowering

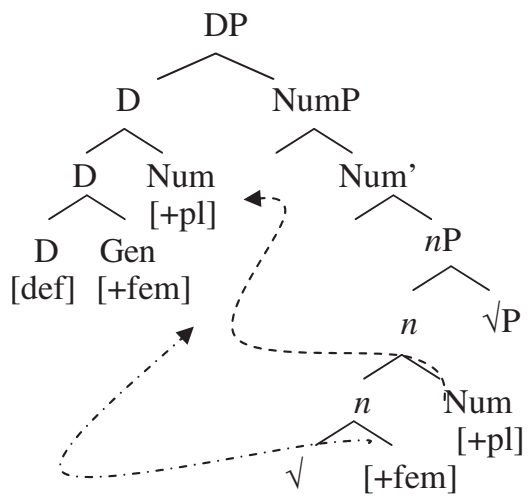

(ii) concord

Assuming now that nominal ellipsis is $n \mathrm{P}$ ellipsis with gender specified on $n$, two consequences follow immediately. On the one hand, we predict gender invariance between a given nominal antecedent and the elliptical $n \mathrm{P}$. In effect, as already mentioned, given that gender specification is part of the elliptical gap, it has to be identical to the antecedent; consequently, no gender mismatch is allowed. This prediction is fulfilled as can be seen in (59). On the other hand, number can vary because it is outside the elliptical gap (cf. 60).
a. *Juan prefiere a su perro más que a la Juan prefers to his dog.MSC.SG more than to the.F.SG perra de Pedro. dog.E-SG of Pedro
b. *Juan prefiere a su perra más que al Juan prefers to his dog.F.SG more than to.the.MSC.SG perro de Pedro. deg.F-SG of Pedro 
c. *Juan visitó a su tía y Pedro visitó Juan visited to his aunt.F.SG and Pedro visited al suyo

to.the.MSC.SG tnele.AsG-SG his

d. *Juan visitó a su tío y Pedro visitó a Juan visited to his uncle.MSC.SG and Pedro visited to la suya the.F.SG aunt.F-SG her

(60) a. Juan prefiere a su perro más que a los Juan prefers to his dog.MSC.SG more than to the.MSC.PL perres de Pedro. deg.:ASG:PE of Pedro

b. Juan compró dos libros de Borges y María compró Juan bought two books of Borges and Maria bought uno libre de Cortázar. one book of Cortázar

c. Juan compró un libro de Borges y María compró dos Juan bought one book of Borges and Maria bought two libres de Cortázar. books of Cortázar

In other words, the asymmetric behavior between number and gender in contexts of nominal ellipsis does not follow from the putative syntactic vs. lexical nature of number and gender respectively (see Depiante \& Masullo 2001, Kornfeld \& Saab 2004 and Eguren 2010, among others) but from the size of the elliptical gap and the distribution of inflectional features in the structure of the DP (in consonance with Saab 2004, 2008 and 2010 and what we have observed for Hungarian in section 4.2, ex. 36). In this respect, partial identity effects, with respect to number, parallel the behavior of tense in VP ellipsis contexts. Compare, for instance, VP ellipsis and TP ellipsis in the sentential domain. As is well known, English VP ellipsis tolerates differences in tense features (Lasnik 1999, among many others) whereas Spanish TP ellipsis does not (Brucart 1987, Murguia 2004 and Saab 2008, among others):

(61) John went to the cinema and I will too.

(62) *María ha leído mucho y Elena en el futuro María has read a-lot and Elena in the future habrá leído muche también. will have read a lot also

'María has read a lot and Elena in the future will have too.'

(Murguia 2004:86)

As shown in Saab (2010), the same asymmetry is found in the DP domain, where $n \mathrm{P}$ ellipsis cases like (60) contrast with certain instances 
on NumP ellipses in English that do not tolerate number differences between the antecedent and the elliptical phrase.

(63) a. John's coat and Peter's [eeat/*ceats]

b. I saw John's daughter, and then Peter's [daughter/*daughters]

c. John's coats and Peter's [eoats/*coat]

d. I saw John's daughters, and then Peter's [daughters/*daughter]

As extensively argued in Lobeck (1995), the ellipses in (63) should be analyzed as instances of NumP ellipsis. If this is on the right track, we are led to conclude that inflectional asymmetries of intrerpretable features like number or tense across different types of deletion phenomena are derived from the size of the elliptical constituent and not from the lexical $v s$. non-lexical distinction.

A related (and crucial) consequence of this approach is that if the NumP $v s . n \mathrm{P}$ distinction between ellipsis sites exists, and both NumP and $n \mathrm{P}$ are elidable in Spanish, then only $n \mathrm{P}$ ellipsis should create a stranded affix filter configuration with respect to Num, since NumP ellipsis elides the number marking altogether. In the rest of this section, we show that this prediction is borne out.

Interestingly, the kind of data that show this clearly are examples in which an inflected determiner head is not required in Spanish elliptical DPs. The following illustration comes from Eguren (2010), who has extensively discussed some cases of ellipsis in the nominal domain that appear to be licensed by adjectives or PP remnants.

(64) a. Antes bebía cerveza alemana y ahora solo bebo before drank.1SG beer German and now only drink.1SG española. Spanish

'I used to drink German beer before and I only drink Spanish [beer] now'.

b. No había leído cuentos de Cortázar, pero sí había no had.1SG read stories of Cortázar but yes had.1SG leído de Borges. read of Borges

'She had not read stories by Cortázar, but she HAD read [stories] by Borges'.

c. Al principio llegaron estudiantes de físicas y luego to.the beginning came.3PL students of physics and then llegaron de químicas. came.3PL of chemistry

'There first came students of physics and then there came [students] of chemistry'.

(Eguren 2010:437)

Examples such as these are taken by Eguren as a counterargument to the licensing condition, as formulated by Lobeck (1995), repeated in (65) 
from section 2.1. above, and as an argument in favor of his contrastive focus condition on ellipsis (cf. 66, see also Giannakidou \& Stavrou 1999 for a related view).

(65) Licensing and Identification of pro

An empty, non-arbitrary pronominal must be properly headgoverned, and governed by an $\mathrm{X}^{0}$ specified for strong agreement.

(Lobeck 1995:20)

(66) Contrastive focus (in nominal ellipsis):

Contrastive focus identifies a relevant alternative or subset in a set of contextually or situationally given alternatives, and the focused constituent(s) in the remnant cannot be (semantically) identical to the corresponding part(s) in the antecedent phrase.

(Eguren 2010:443)

In our view however, the data in (64) do not represent a real counterargument to licensing, but show that Spanish has NumP ellipsis in addition to well-known cases of $n \mathrm{P}$ ellipsis. Evidence for this claim comes from the observation that ellipsis within DPs with adjectives or PPs as the only remnants does not allow for number variation between the antecedent and the elliptical gap. Compare (67a) from Eguren (2010:437) with (67b), where the antecedent is singular and the elided noun is plural.

(67) a. Es mucho más fácil cortar la carne con cuchillos is much more easy to.cut the meat with knifes buenos que con euchillos malos. good that with knives bad.PL

'It is much easier to cut the meat with good knives than with bad ones'.

b. *?Es mucho más fácil cortar la carne con un cuchillo is much more easy to.cut the meat with a knife bueno que con emehilles malos. good.sG that with knives bad.PL

'It is much easier to cut the meat with a good knife than with bad ones'.

The same effect is found when the elliptical gap is modified by a PP remnant:

(68) a. Juan me dio un libro de Borges aunque yo quería Juan me gave a book of $B$. although I wanted algunos/varios libres de Cortázar.

some/several books of $\mathrm{C}$.

'Juan gave me a book by Borges although I wanted some / several books by Cortázar.' 
b. *?Juan me dio un libro de Borges aunque yo quería Juan me gave a book of Borges although I wanted libres de Cortázar. books of Cortázar

'Juan gave me a book by Borges although I wanted books by Cortázar.'

It seems then that there is a correlation between the type of ellipsis in the nominal domain and the presence of obligatory inflected material as remnant: only nominal ellipses that require overt number marking on the remnant material tolerate number asymmetries between the antecedent phrase and the elided nominal. Part of this generalization is accounted for if one assumes, as we do here, that ellipsis can elide either an $n \mathrm{P}$ or a NumP constituent. With this distinction made, we can retain the generalization that Spanish requires overt number inflection in nominal ellipsis contexts. Our next step now is to provide a principled explanation for this.

\subsection{Circumventing the stranded affix filter by deletion}

On the basis of the previous discussion we conclude that $n \mathrm{P}$ ellipsis in Spanish, just like the languages we looked at in section 4 , creates a stranded affix filter scenario. This is because lowering from Num to $n$ is blocked under $n \mathrm{P}$ ellipsis.

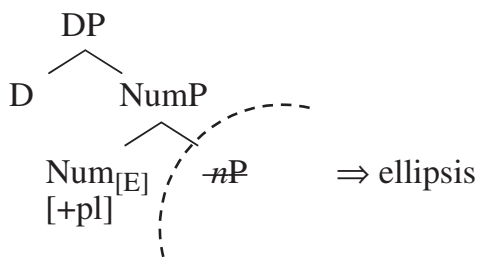

In other words, Spanish $n \mathrm{P}$ ellipsis instantiates another case of the Elmogeneralization we introduced in section 3 (cf. 17 repeated below as 70).

(70) Ellipsis-Morphology Generalization (Elmo-generalization)

For every morphological operation $\mathrm{MO}$ that affects the domain of

$\mathrm{X}$, where $\mathrm{X}$ contains the target of $\mathrm{MO}, \mathrm{MO}$ cannot apply in $\mathrm{X}$ if $\mathrm{X}$ is subject to ellipsis.

However, unlike agglutinative languages, Spanish does not rescue the stranded affix via Morphological Merger, but rather, via Morphological Ellipsis. In this respect, the presence of number marking on the remnant determiner in $n \mathrm{P}$ ellipsis is the overt reflex of the complex interaction between ellipsis and morphology. (71) repeats our basic case: 
(71) ¿\{Qué/cuáles\} libros de Borges y $\left\{{ }^{*}\right.$ qué/cuáles\}

what/which.PL books of Borges and *what/which.PL

libres de Bioy te gustan?

books of Bioy CL like

'Which books of Borges and which of Bioy do you like?'

In section 2.2., we proposed that Morphological Ellipsis proceeds under the same locality conditions as Morphological Merger (recall 14 from above):

(72) Morphological Ellipsis: at PF, a morphosyntactic word (MWd) $\mathrm{X}^{0}$ can be elided only if $\mathrm{X}^{0}$ has an identical antecedent contained in a MWd $\mathrm{Y}^{0}$ adjacent or immediate local to $\mathrm{X}^{0}$.

Notice now that this approach nicely accounts for our basic contrast in (71). Concretely, the derivation of this minimal pair proceeds as follows. The dissociated number morpheme realized on cuál(es) allows head ellipsis of the stranded Num head under immediate locality (i.e., the D head licenses ellipsis of the head of its complement, NumP), thus circumventing the problem caused by a potential stranded affix.

Let us see the essential steps for the derivation of inflected cuáles in the second conjunt of (71). In the syntax, a Num head with an [E] feature triggers ellipsis of its $n \mathrm{P}$ complement by marking it as not being subjected to lexical insertion (see Saab 2008 for an explicit formulation of this aspect of the theory of ellipsis). As shown in (73a), we also assume that the possessor phrase de Bioy moves as a remnant out of the elliptical site, but the point is orthogonal to the main argument we are making here. By the Elmo (70), Num cannot lower to $\mathrm{N}$ at PF and it is left stranded. Number concord, however, applies normally copying the number feature $[+\mathrm{pl}]$ onto a dissociated number morpheme in the $\mathrm{D}$ head (73b). It is by virtue of this operation that the environment for head ellipsis, as defined in (72), is created and the stranded affix is eliminated by ellipsis. As illustrated in (73c), the relevant structural condition that licenses head ellipsis is immediate locality between D and Num (i.e., the head projeting the $\mathrm{D}$ complement). 
100 Andrés Saab \& Anikó Lipták

(73) a. Syntax: Ellipsis of the $n \mathrm{P}$ triggered by [E] on Num

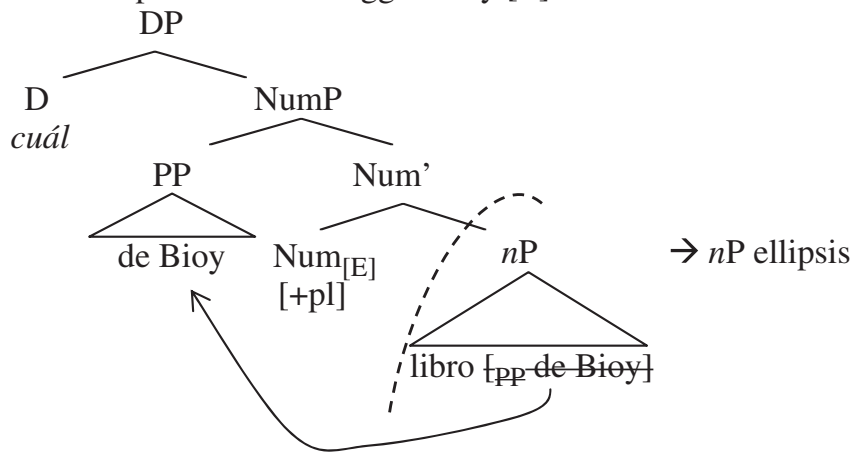

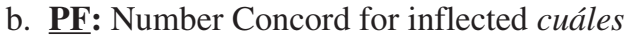

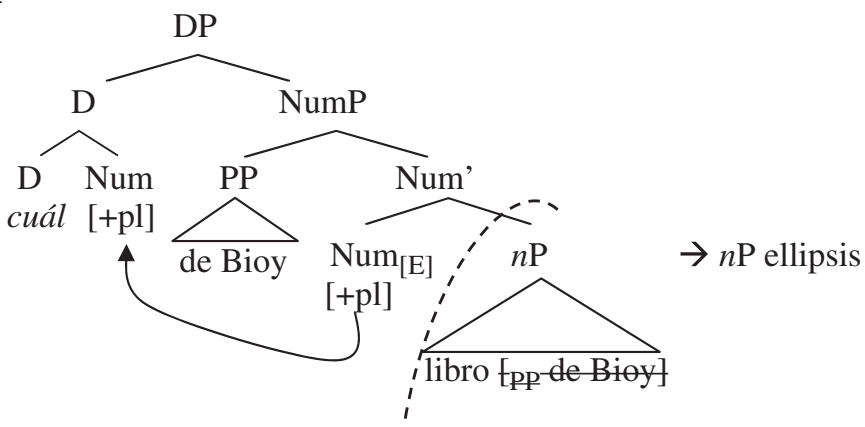

c. PF: Num deletion via morphological ellipsis (i.e., 72)

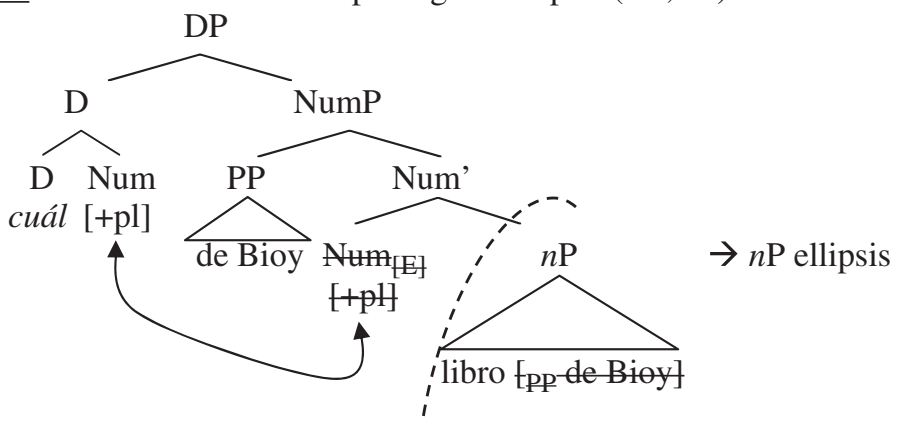

With this in place, it is now clear why invariable qué, which do not show number concord, is not a legitimate remnant in nominal ellipsis enviroments: the derivation crashes due to a stranded affix filter violation. 


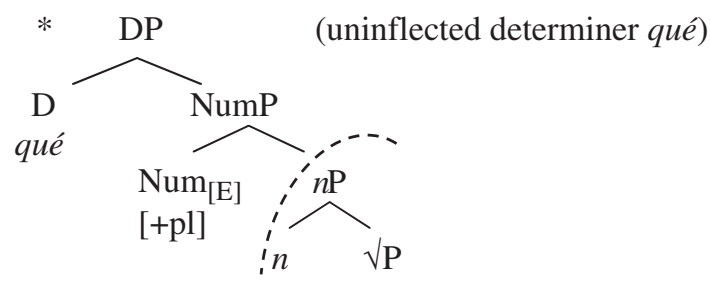

Crucially, no licensing mechanism for ellipsis is involved in this account (beyond of course the presence of the abstract [E] feature in the syntax), because concord, as an independent operation of the Spanish grammar, creates the configuration that triggers head ellipsis in the morphological component.

The ellipsis operation in (73c) takes place in the same configuration as Lowering at PF: under immediate locality (see 72). Independent evidence for this comes from agreeing demonstratives in Hungarian. As shown in (75) demonstrative $a z$ in Hungarian inflects in number:

(75) az-ok-at a szép ház-ak-at

that-PL-ACC the nice house-PL-ACC

'those nice houses'

In contexts of nominal ellipsis, however, inflected demonstratives do not allow for deletion of Num.

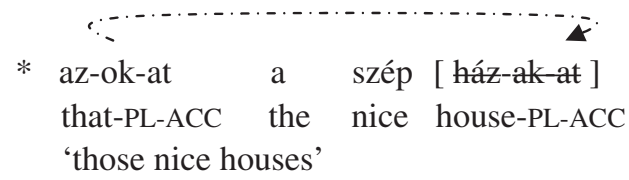

Crucially, the definite article $a$ intervenes between the demonstrative in Spec,DP and the affixal number. This means that the demonstrative is not in the required locality condition for ellipsis to apply.

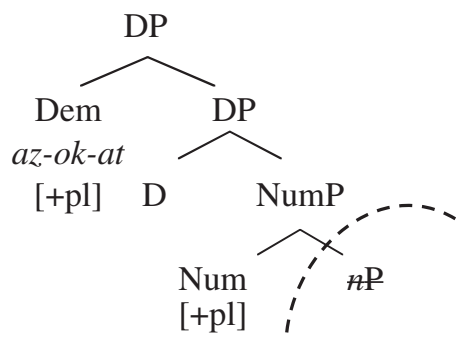

As in normal cases of nominal ellipsis, Hungarian allows for number movement to an adjectival remnant via Local Dislocation to avoid a stranded number morpheme (see section 4.3.): 


$$
\text { az-ok-at a szép-[_]-ek-et }
$$

that-PL-ACC the nice-PL-ACC 'those nice houses'

Interstingly, our number deletion approach also predicts that inflected phrasal remnants in adjoined or specifier positions cannot serve as suitable antecedents for number deletion in Spanish. ${ }^{19}$ The reason is the same as the one we have provided for demonstratives in Hungarian: immediate locality is never met between a phrase and a head. Hence, inflected adjectives in prenominal position do not allow for number deletion. The adjectives distinto( $s)$ 'different' and dicho(s) 'abovementioned' seem to instantiate this scenario:

$$
\begin{aligned}
& \text { a. La noticia se publicó en dos periódicos de Madrid } \\
& \text { the new SE published in two newspapers of } \mathrm{M} \\
& \mathrm{y} \text { en distint-o-s * (periódicos) de Barcelona. } \\
& \text { and in different-MASC-PL newspapers of B. } \\
& \text { 'The information was published in two newspapers in Madrid } \\
& \text { and in different newspapers in Barcelona'. }
\end{aligned}
$$

${ }^{19}$ The same might hold for the case of tal 'such', mentioned by Eguren (as another counterevidence to theories capitalizing on inflectional licensing). Tal behaves morphologically just like cuál(es) in that it inflects only in number (tal 'such.SG' / tales 'such.PL'). Yet, even though it inflects, it never licenses nominal ellipsis. See the following examples and, in particular, the minimal pair in (ii) where interrogative cuáles radically contrasts with tales:

(i) Tengo graves problemas y no sé qué hacer ante tales*(problemas). have.1SG serious problems and not know.1SG what to.do with such.PL

'I have serious problems and I do not know what to do with such problems'.

(ii) a. *tales estudiantes de física y tales de lingüística

(Eguren 2010: 439) such-PL students of physics and such.PL of linguistics 'such students of physics and such of linguistics'

b. cuáles estudiantes de física y cuáles de lingüística? which.PL students of physics and which.PL of linguistics 'which students of physics and which ones of linguistics'

In our view, what explains this behavior is that tal cannot license number deletion under immediate locality, precisely because the required local relation between licenser and licensee is not met. We take tal to be a degree phrase that is positioned higher than the $\mathrm{Num}^{0}$ head. For illustration, we place it in the specifier of NumP itself (the exact position being orthogonal to our point here). Independent evidence for the phrasal nature of tal is that it can be in a specifier position of a $\mathrm{P}$ head, like in the fixed expression tal para cual (Lit. such for which, 'two of the same kind'), and it can be the modifier of vez 'time' or even cual 'which' to form complex, modal expressions like tal vez 'maybe' and tal cual, 'exactly'.

An alternative analysis, also compatible with our approach, is to assume that tal(es) can indeed occupy the $\mathrm{D}$ position but it takes as a complement a degree phrase that intervenes between $\mathrm{D}$ and Num. This intervening head destroys the immediate locality relation between them. We leave the issue open for further research. 
b. Algunos periodistas están enfadados. Dich-o-s some journalists are angry said-MASC-PL *(periodistas) critican al gobierno. journalists criticize to-the government 'Some journalists are angry. The above-mentioned journalists criticize the government'.

(Eguren 2010:439)

According to Eguren (2010), these examples show again that inflection cannot play any role in the formal licensing of ellipsis. Our interpretation of the data in (79) is radically different from the conclusion held by Eguren. According to our view, number inflected adjectives of this type cannot license Num head deletion ( $n \mathrm{P}$-ellipsis is not at issue) because immediate locality is not satisfied; they are adjectives in some adjoined or specifier position in the nominal domain. ${ }^{20}$ For the sake of the exposition, let us assume that they are specifiers of Num, as shown in (80), for dichos in the second sentence of (79b):

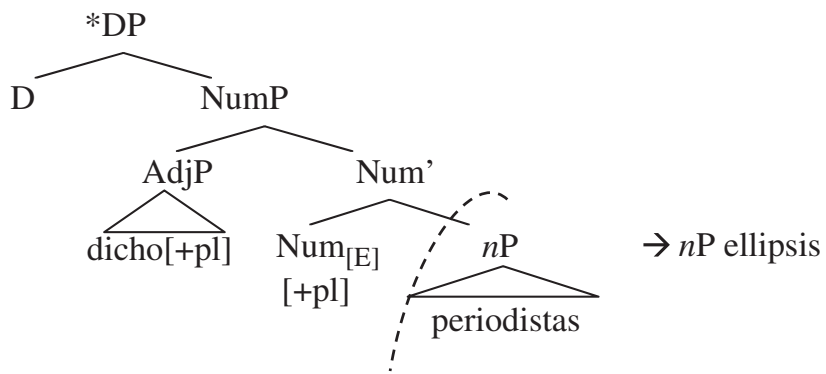

As it is clear, the potential antecedent for the deletion of the Num head, namely, the dissociated number morpheme in the adjective, is not in

${ }^{20}$ Eguren analyzes these adjectives as determiners. The putative evidence he provides is that they license prenominal subjects in Spanish (Eguren 2010: footnote 8, 439). We think that this is not a conclusive argument. Assuming, for instance, that prenominal subjects in Spanish require some phonological realization of $\mathrm{D}$, either by means of marking $\mathrm{D}$ itself or by merging a specifier with it (see Landau 2007 for such an approach), an adjective as distinto can straightforwardly be analyzed as a phrasal category merged with a null $\mathrm{D}$. This instance of merge licenses prenominal subjects without a visible D head. 


\section{Andrés Saab \& Anikó Lipták}

the required position for head ellipsis to apply under immediate locality. ${ }^{21}$

In sum, in this section we have shown how to derive Lobeck-type 'government' effects in the Spanish DP with the tools available in the DM framework. The role of inflection in the nominal domain in this framework reduces to the need for a suitable antecedent for morphological deletion, an operation subject to the same conditions that apply for morphological displacement. This analysis not only has the explanatory force of deriving the government effects with certain determiners, but also provides novel evidence for the type of locality relations that are required in the postsyntactic component.

\section{Conclusion}

In this paper, we took a fresh perspective on the role of inflection in nominal ellipsis and advanced a generalization that can explain why number inflection is obligatorily present in elliptical noun phrases in languages where nouns inflect for number.

We have argued that the reason why languages show overt inflection in this particular syntactic domain is not related to licensing (either in the form of head-government as in Lobeck 1995 or in the form of [E]-feature checking as in Merchant 2001). Instead, we showed that inflection is overt in NP ellipsis because of an interaction between ellipsis and morphology. Taking the view that morphological operations are syntac-

${ }^{21}$ Yet, other prenominal material, like numerals and adjectives like otro $(s)$ [other(s)], does license Num deletion. In Saab (2008), where examples like (79) are not taken into consideration, it is proposed that such prenominal material can license number deletion under adjacency. The motivation for such an approach is provided by examples like (i), where the adding of inflected otras to invariable qué seems to be enough to license nominal ellipsis (example from Saab 2008, where the case of numerals is also analyzed in detail):

(i) A: Vi varias películas de suspenso este fin de semana. Cabo de miedo me saw.1SG several suspense of movies this weekend Cabo de miedo me encantó.

loved

'I saw several detective movies this weekend. I loved Cabo de miedo.'

B: ¿Qué otra pelíetla de suspenso viste?

what other.FEM.SG of suspense saw.2SG

'Which other detective movie did you see?'

B': ¿Qué otras pelíetlas de suspenso viste?

what other.FEM.PL of suspense saw.2SG

'Which other detective movies did you see?'

In view of the contrast between this type of examples and examples like (79), an alternative analysis to Saab (2008) would be to postulate that numerals and adjectives like otro head their own projections and select NumP as their complements. If this is on the right track, then Num in cases like (i) would be deleted under immediate locality in the exactly the same way we propose for variable cuáles in (71). At any rate, both analyses leave open the question on why Num ellipsis is not allowed under adjacency in examples like (79), although adjacency does license head ellipsis in other contexts (see Saab 2008 for detailed discussion). 
tic in nature and occur after spell-out, we put forward the proposal that morphological operations interact with ellipsis (defined as vocabulary non-insertion) in PF in complex ways. In the particular type of ellipsis to which the discussion was dedicated to, NP ellipsis, we demonstrated that ellipsis blocks morphological operations that apply in PF because it removes the host of certain affixes. In languages in which number marking is the result of morphological operations in PF such as lowering of a number affix, this means that ellipsis can give rise to stranded affix filter violations.

We have shown evidence for this kind of stranding in agglutinative languages, such as Hungarian, Turkish, and Quechua, and we argued that in these languages, the stranded number affixes are rescued by various sorts of morphological merger that provide them with a suitable host. We have concluded that the same effect can also be observed in Spanish, but that in this language the rescue operation employed to save the stranded affix is that of deletion under concord. With this we have identified alternative strategies of rescuing stranded affix filter violations and set the first step towards understanding parametric variation among languages in the nominal domain when it comes to the morphology of elliptical noun phrases.

Finally, we would like to mention a consequence of our theory for the study of word formation. We believe the fact that agglutinative languages allow for NP ellipsis to target the noun to the exclusion of inflectional material affixed to it provides evidence against strongly lexicalist approaches to word formation. Strongly lexicalist approaches would not allow a syntactic operation like ellipsis to have access to the internal structure of the affixed word (usually put down to the effect of the Lexical integrity/Word Structure Autonomy Condition, Selkirk 1982, Booij 1985). Non-lexicalist accounts on the other hand, such as Distributed Morphology (which we implemented in our analysis), have no problem deriving these facts.

\section{References}

Aelbrecht, L. 2009. You have the right to remain silent: The syntactic licensing of ellipsis. Phd Dissertation, Catholic University of Brussels.

Alexiadou, A. 2001. Functional structure in nominals. Amsterdam: John Benjamins.

Alexiadou, A. \& Gengel, K. 2012. NP Ellipsis without Focus movement/ projections: the role of Classifiers. Contrast and positions in Information Structure. eds. In I. Kučerová \& A. Neeleman, 177-205. Cambridge: Cambridge University Press.

Bartos, H. 2000a. VP-ellipsis and verbal inflection in Hungarian. Acta Linguistica Hungarica 47:3-23.

Bartos, H. 2000b. Az inflexiós jelenségek szintaktikai háttere. Strukturális magyar nyelvtan 3. Morfológia. ed. F. Kiefer, 653-761. Budapest: Akadémiai Kiadó, Budapest. 
Bartos, H. 2001a. Sound-form non-insertion and the direction of ellipsis. Acta Linguistica Hungarica 48:3-24.

BArtos, H. 2001b. A mutató névmási módosítók a magyarban: egyeztetés vagy osztozás? Újabb tanulmányok a strukturális magyar nyelvtan és a nyelvtörténet köréből. eds. M. Barkó-Nagy, Z. Bánréti \& K. E. Kiss, 19-41. Budapest: Osiris.

Bernstein, J. 1993. The syntactic role of word markers in null nominal constructions. Probus 5:5-38.

BobalJik, J. 1995. Morphosyntax: the syntax of verbal inflection. Phd Dissertation, MIT.

BoolJ, G. 1985. Coordination reduction in complex words: A case for prosodic phonology. Advances in nonlinear phonology. eds. H. van der Hulst \& N. Smith, 143-60. Dordrecht: Foris.

Bosque, I. \& Picallo, C. 1996. Postnominal adjectives in Spanish DPs. Journal of Linguistics 32:1-36.

Bouchard, D. 2002. Adjectives, number and interfaces. Why languages vary. Amsterdam: Elsevier.

Brody, M. 2000. Mirror theory: syntactic representation in Perfect Syntax. Linguistic Inquiry 31:29-56.

BrucArt, J. M. 1987. La elisión sintáctica en español. Barcelona: Bellaterra.

Cheng, L. \& Sybesma, R. 2005. Classifiers in four varieties of Chinese. The Oxford Handbook of Comparative Syntax. eds. G. Cinque \& R. Kayne, 259292. New York: Oxford University Press.

Cheng, L. \& Sybesma, R. 2009. De, 的 as an underspecified classifier: first exploration. Yuyanxue Luncong 39:123-156. Beijing: The Commercial Press.

Chomsky, N. 1995. The minimalist program. Cambridge, Mass.: MIT Press.

Cinque, G. 2010. The syntax of adjectives. A comparative study. Cambridge, MA: MIT Press.

Cole, P. 1982. Imbabura Quechua. Amsterdam: North-Holland Publishing Company.

Corver, N. \& van Koppen, M. 2011. NP-ellipsis with adjectival remnants: a micro-comparative perspective. Natural Language and Linguistic Theory 29: $371-421$.

Cyrino, S. \& Matos, G. 2002. VP-ellipsis in European and Brazilian Portuguese: a comparative analysis. Journal of Portuguese Linguistics 1:177-195.

DÉKÁNY, É. 2011. A prole of the Hungarian DP. The interaction of lexicalization, agreement and linearization with the functional sequence. Phd Dissertation, Tromsø.

DékÁNY, É. to appear. The syntax of anaphoric possessives in Hungarian. Natural Language and Linguistic Theory.

Eмвick, D. 2007. Linearization and local dislocation: Derivational mechanics and interactions. Linguistic Analysis 33:2-35.

Embick, D. \& Noyer, R. 2001. Movement operations after syntax. Linguistic Inquiry 32:555-595.

Eguren, L. 2010. Contrastive focus and nominal ellipsis in Spanish. Lingua 120/ 2:435-457.

É. KIss, K. 2002. The syntax of Hungarian. Oxford: Oxford University Press.

FABB, N. 1984. Syntactic affixation. Phd Dissertation, MIT.

FAß, E. 2008. Multiple agreement and the representation of inflection in the Cdomain. Linguistische Berichte 213. 78-208.

Gengel, K. 2007. Focus and ellipsis: A generative analysis of pseudogapping and other elliptical structures. Phd Dissertation, University of Stuttgart.

Giannakidou, A., \& Stavrou, M. 1999. Nominalization and ellipsis in the Greek DP. The Linguistic Review 16:295-332. 
Ghaniabadi, S. 2010. The empty noun construction in Persian. Phd Dissertation, University of Manitoba.

GoldberG, L. 2005. Verb-stranding VP-ellipsis: A cross-linguistic study. Phd Dissertation, University of McGill.

Halle, M. \& Marantz, A. 1993. Distributed Morphology and the pieces of inflection. The view from building 20. eds. K. Hale \& S. Keyser, 111-176. Cambridge MA: MIT Press.

Hankamer, J. 2005. Why there are two $-k i$ 's in Turkish. Ms., USC.

JACKENDOFF, R. 1977. X-bar syntax: A study of phrase structure. Cambridge, MA: MIT Press

Kester, E. 1996a. The nature of adjectival inflection. OTS Dissertation Series, University of Utrecht.

Kester, E. 1996b. Adjectival inflection and the licensing of empty categories in DP. Journal of Linguistics 32:57-78.

Kornfeld, L. \& SAAB, A. Nominal ellipsis and morphological structure in Spanish. Romance Languages and Linguistic Theory 2002. eds. R. BokBennema, B. Hollebrandse, B. Kampers-Manhe \& P. Sleeman, 183-198. Amsterdam: John Benjamins.

LaczKó, T. 2007. On elliptical noun phrases in Hungarian. Proceedings of the LFG07 Conference, University of Albany, State University of New York. eds. M. Butt \& T. Holloway King, 323-342. Stanford, CA: CSLI Publications. http:// cslipublications.stanford.edu/LFG/12/lfg07.pdf.

LANDAU, I. 2007. EPP Extensions. Linguistic Inquiry 38(3):485-523.

LASNIK, H. 1981. Restricting the theory of transformations: A case study. Explanation in Linguistics. eds. N. Hornstein \& D. Lightfoot, 152-173. London: Longmans.

LASNIK, H. 1999. Verbal morphology: Syntactic Structures meets the Minimalist Program. Minimalist Analysis. Malden MA: Blackwell, 97-199.

LiPTÁK, A. \& SAAB, A. 2014. No N-raising out of NPs in Spanish: ellipsis as a diagnostic of head movement. Natural Language and Linguistic Theory 32:1242-1271.

Lobeck, A. 1995. Ellipsis: Functional heads, licensing and identification. New York: Oxford University Press.

LóPez, L. 2000. Ellipsis and discourse linking. Lingua 110:183-213.

McFadden, T. 2002. The morphosyntax of Finno-Ugric case-marking: a DM account. Proceedings of the North East Linguistic Society 32. ed. M. Hirotani, 347-363.

Merchant, J. 2001. The syntax of silence: sluicing, islands and theory of ellipsis. Oxford: Oxford University Press.

Merchant, J. 2014. Gender mismatches under nominal ellipsis. Lingua 151:9-32.

Murguia, E. 2004. Syntactic identity and locality restrictions on verbal ellipsis. Phd Dissertation, University of Maryland.

Muysken, P \& van Riemsdisk, H. 1986. Features and projections. Dordrecht: Foris.

Ntelitheos, D. \& Christodoulou, E. 2005. The acquisition of nominal ellipsis in Greek. Papers in Psycholinguistics 2, UCLA Working Papers in Linguistics 13. eds. O. Reiko \& K. Nielsen, 14-34.

Nunes, J. \& ZoccA, C. 2009. Lack of morphological identity and ellipsis resolution in Brazilian Portuguese. Minimalist essays on Brazilian Portuguese syntax. ed. J. Nunes, 215-236. Amsterdam: John Benjamins.

PANAgiotidis, P. 2003. Empty nouns. Natural Language and Linguistic Theory 21: 381-432.

Picallo, M. C. 1991. Nominals and nominalizations in Catalan. Probus 3:279316. 


\section{Andrés Saab \& Anikó Lipták}

Ritter, E. 1991. Two functional categories in noun phrases: Evidence from Modern Hebrew. Syntax and Semantics 25: Perspectives on phrase structure. ed. S. Rohstein, 37-62. New York: Academic Press.

RizzI, L. 1986. Null objects in Italian and the theory of pro. Linguistic Inquiry 17: 501-557.

Ross, J. 1967. Constraints on variables in syntax. Phd Dissertation, MIT.

SAAB, A. 2004. El dominio de la elipsis nominal en español. Master Thesis, National University of Comahue.

SAAB, A. 2008. Hacía una teoría de la identidad parcial en la elipsis. Phd Dissertation, University of Buenos Aires.

SAAB, A. 2010. (Im)possible deletions in the Spanish DP. Iberia 2.2:45-83.

Schoorlemmer, E. \& Temmerman, T. 2010. On the interaction between verb movement and ellipsis in the PF-component. Paper presented at GLOW 33, Wroclaw, April 2010.

Schoorlemmer, E. \& Temmerman, T. 2012. Head movement as a PFphenomenon: Evidence from identity under ellipsis. Proceedings of the 29th West Coast Conference on Formal Linguistics, 232-240. Somerville, MA: Cascadilla Press.

Selkirk, E. 1982. The syntax of words. Cambridge MA, MIT Press.

Sleeman, P. 1996. Licensing empty nouns in French. Phd Dissertation, University of Amsterdam.

StJePanovic, S. 2011. Genitive of Quantification in Slavic: A view from ellipsis. Paper presented at FASL 20, MIT.

Temmerman, T. 2012. Multidominance, ellipsis and quantifier scope. Phd Dissertation, Leiden University.

Weber, D. 1983. Relativization and nominalized clauses in Huallaga Quechua. Berkeley: University of California Press.

Received June 4, 2013

Accepted March 14, 2014

Andrés Saab

Instituto de Filología y Literaturas Hispánicas "Dr. Amado Alonso"

University of Buenos Aires

CONICET

25 de mayo $221,1^{\text {st }}$ floor

(1002) Buenos Aires

Argentina

al_saab75@yahoo.com.ar

Anikó Lipták

LUCL

Leiden University

P.O. Box 9515

2300 RA Leiden

The Netherlands

a.k.liptak@hum.leidenuniv.nl 